\title{
Petrology, petrogenesis and tectonic setting of plutonic rocks in the North Mountain area, west-central Cape Breton Island, Nova Scotia
}

\author{
Mario F. Justino and Sandra M. Barr \\ Department of Geology, Acadia University, Wolfville, Nova Scotia BOP IX0, Canada
}

Date Received December 21, 1993

Date Accepted April 26, 1994

\begin{abstract}
The Marble Mountain area of west-central Cape Breton Island is underlain mainly by granitoid rocks of the Marble Mountain, Big Brook, and West Bay plutons, migmatitic gneisses of the Lime Hill gneissic complex, and low-grade metasedimentary rocks of the Malagawatch Formation. The Late Precambrian Marble Mountain and Big Brook plutons are composed of hornblende-biotite tonalite to granodiorite. These plutons underwent similar but separate evolutionary histories involving fractionation of plagioclase and hornblende \pm biotite. They display petrological similarities to Cordilleran I-type suites, as exemplified by the Peninsular Ranges Batholith, and are interpreted to have formed by partial melting of a mainly basaltic source, and to represent the root zone of a primitive volcanic arc at a convergent plate margin. In contrast, the West Bay Pluton consists of megacrystic monzogranite and associated, probably co-genetic, granitic porphyritic dykes. The pluton is a felsic granite with I-type mineralogy but displays evolutionary trends distinct from typical felsic I-, S-, and A-type granites. The tectonic setting is interpreted to be post-orogenic, and the magma may have formed by a high degree of partial melting of a mainly crustal source. The age of the West Bay Pluton is uncertain, but may be Early Ordovician, based on petrological similarity to other granitic plutons in the Bras d'Or terrane which have yielded U.Pb (zircon) ages of ca. $495 \mathrm{Ma}$.

La région du mont Marble du centre-ouest de l'île-du-Cap-Breton comprend principalement des roches granitiques des plutons du mont Marble, du ruisseau Big et de la baie Ouest, des gneiss migmatitiques du complexe gneissique de la colline Hill et des roches métasédimentaires de faible grade de la Formation de Mallagawatch. Les plutons du mont Marble et du ruisseau Big, du précambrien tardif sont composés de tonalite à homblende et biotite et de granodiorite. Ces plutons ont connu des évolutions distinctes mais similaires impliquant la cristallisation fractionnée du plagioclase et de la hornblende $t$ biotite. Ils montrent des similarités pétrologiques avec les suites de type I de la Cordillière, comme par exemple le batholite de Puninsular Ranges, et sont interprétés comme ayant été formés par la fusion partielle d'une source principalement basaltique, et représentant le soubassement d'un arc volcanique primitif à une bordure de plaques convergentes. En contraste, le pluton de la baie Ouest consiste en monzogranite à mégacristaux et en dykes de granite porphyrique associés et probablement cogénétiques. Le pluton est un granite felsique avec une minéralogie de type I mais qui montre des tendances évolutives distinctes des granites felsiques des types I, $\mathrm{S}$ et $\mathrm{A}$. L'environnement tectonique est interprété comme étant post-orogénique, et le magma pourrait s'être formé par un taux élevé de fusion partielle d'une source principalement crustale. L'âge du pluton de la baie Ouest est incertain, mais pourrait être Ordovicien précoce, d'après les similarités pétrologiques avec d'autres plutons granitiques dans le terrain de Bras d'Or, lesquels ont fourni des âges U-Pb (zircons) d'environ $495 \mathrm{Ma}$.
\end{abstract}

[Traduit par la rédaction]

\section{INTRODUCTION}

The North Mountain area in west-central Cape Breton Island (Fig. 1) is underlain by varied granitoid and metamorphic rocks (Fletcher, 1881; Guernsey, 1928; Kelley, 1967; Milligan, 1970). The area is part of the Bras d'Or terrane (Barr and Raeside, 1989; Raeside and Barr, 1990), and hosts significant mineral deposits (Milligan, 1970; Sangster et al., 1990a). This paper is based on a M.Sc. thesis project (Justino, 1991) which focused on the geology of the granitoid rocks of North Mountain. It describes the field relations, petrography, and geochemistry of the granitoid rocks, and interprets their petrogenesis and tectonic setting.

\section{Geological setTing}

The Bras d'Or terrane is characterized by low-pressure cordierite-andalusite gneiss, low- to high-grade metasedimentary and minor metavolcanic rocks, and abundant plutonic rocks
(Raeside and Barr, 1990). Many of the plutonic units have U$\mathrm{Pb}$ (zircon) ages of 565 to $555 \mathrm{Ma}$, but locally granitic plutons yielded ages of ca. $495 \mathrm{Ma}$ (Dunning et al., 1990; Barr et al., 1990). The Bras d'Or terrane has been correlated with areas in both southern Newfoundland and New Brunswick (Barr and Raeside, 1989; Barr et al., 1990; Raeside and Barr, 1990), but its regional significance and relationship to the adjacent Mira terrane are controversial (e.g., Keppie et al., 1990, 1991).

In the North Mountain area, the characteristic metamorphic units of the Bras d'Or terrane are represented by the Lime Hill gneissic complex and Malagawatch Formation (Fig. 1), both of which were included in the George River Group prior to the present study (Chatterjee, 1980; Kelley, 1967; Milligan, 1970). The Lime Hill gneissic complex consists of polydeformed migmatitic paragneiss and less abundant orthogneiss, amphibolite, marble, and calc-silicate rocks, intruded by granitoid sheets of varied composition. Marble units in the complex host the Lime Hill zinc occurrence (Sangster et al., 1990a). The age of the complex is uncertain, but Late Precambrian to Early Cam- 


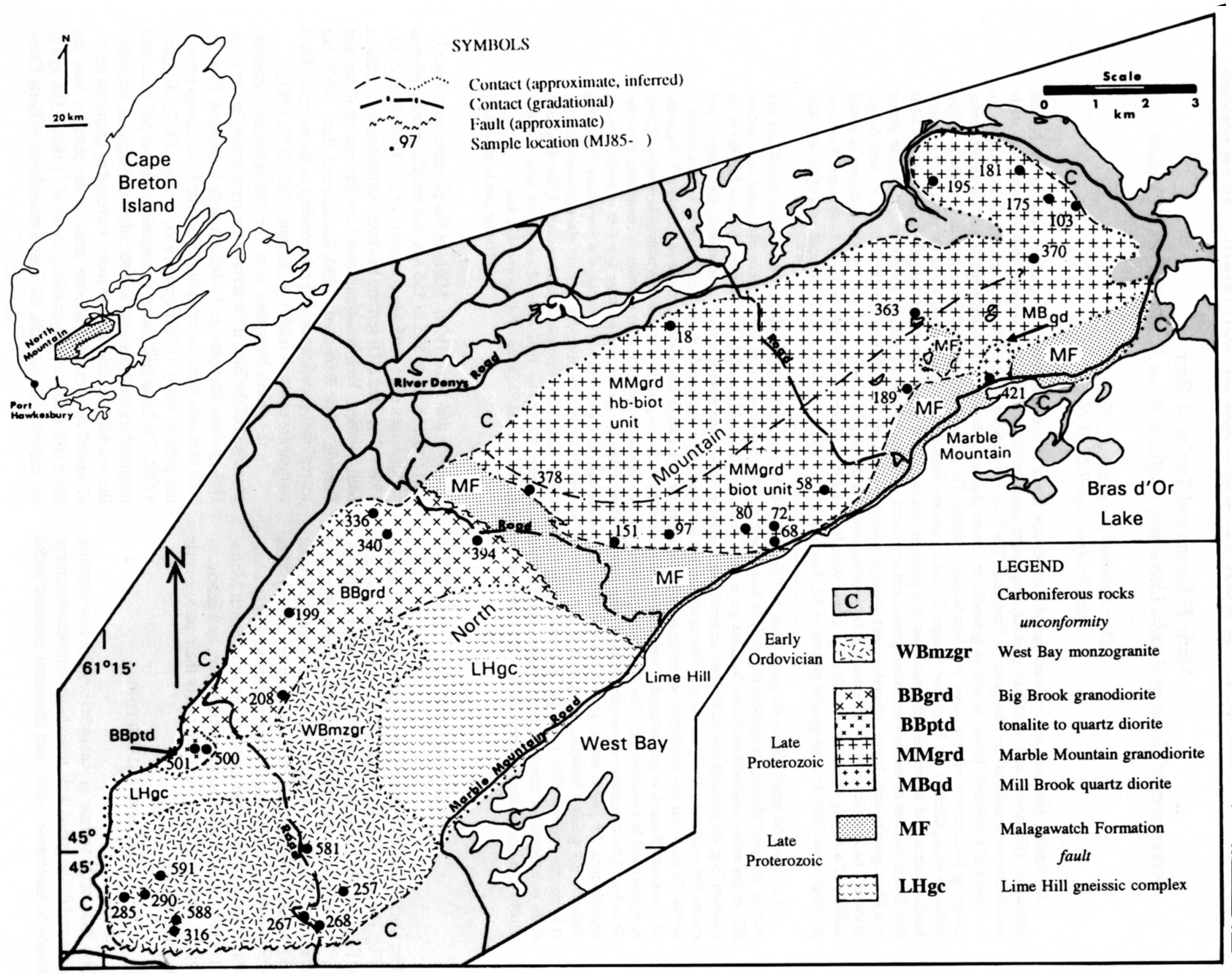

Fig. 1. Geology of the North Mountain area in west-central Cape Breton Island (after Justino, 1991) 
brian dates from granitic sheets in the complex (Sangster et al., 1990b) provide a minimum age. The Malagawatch Formation is composed mainly of low-grade metapelite, calcitic and dolomitic carbonate-bearing rocks, quartzite, and minor mafic metavolcanic rocks. The age of the formation and its relationship to the Lime Hill gneissic complex are uncertain (Raeside and Barr, 1990; Sangster et al., 1990a, b).

Based on field studies and petrography (Justino, 1991), the granitoid rocks of the North Mountain area are divided into the Marble Mountain, Big Brook, and West Bay plutons. In addition to these large bodies, a small pluton (Mill Brook quartz diorite) occurs southeast of the Marble Mountain Pluton and an unnamed tonalite-diorite body occurs southwest of the Big Brook Pluton (Fig. 1).

Keppie et al. (1990) reported ${ }^{40} \mathrm{Ar} /{ }^{39} \mathrm{Ar}$ dates of $555 \pm 5$ $\mathrm{Ma}$ and $545 \pm 6 \mathrm{Ma}$ for hornblende in plutonic units of the North Mountain area; on the basis of locations indicated by Keppie et al. (1990), the former date appears to be from the eastern part of the Marble Mountain Pluton, and the latter from the Mill Brook quartz diorite. These cooling ages are consistent with U-Pb ages of ca. 565 to $555 \mathrm{Ma}$ reported from other dioritic, tonalitic, and granodioritic plutons in the Bras d'Or terrane (Dunning et al., 1990; Barr et al., 1990).

Carboniferous sedimentary rocks unconformably overlie the metamorphic and plutonic rocks around the periphery of North Mountain (Fig. 1).

\section{Field RELATIONS AND PETROGRAPHy}

\section{Marble Mountain Pluton}

The Marble Mountain Pluton consists of grey, medium- to coarse-grained, locally K-feldspar megacrystic granodiorite gradational to tonalite (Fig. 2); for simplicity, it is termed granodiorite. It is subdivided into hornblende-biotite granodiorite and biotite granodiorite units which are inferred to be gradational. The pluton intruded rocks of the Malagawatch Formation which outcrop along its southwestern and southeastern margins. Observed contacts between the pluton and host rocks are steep to vertical. Xenoliths of the Malagawatch Formation occur mostly in the biotite granodiorite, whereas sparse, small, hornblenderich enclaves are abundant in the hornblende-biotite granodiorite. Rare aphanitic to medium-grained granitic dykes and more numerous andesitic and basaltic dykes have intruded the pluton.

Texture in the Marble Mountain Pluton is allotriomorphic to hypidiomorphic granular. Plagioclase occurs as clusters of anhedral to subhedral crystals; grains analyzed by electron microprobe range in composition from $\mathrm{An}_{42}$ to $\mathrm{An}_{25}$ (Justino, 1991). Quartz forms interstitial, fine- to coarse-grained aggregates of anhedral grains with intergrown, irregular boundaries. Potassium feldspar (microcline), in amounts of $1 \%$ to $12 \%$, is also mainly anhedral and interstitial, but locally forms megacrysts in the hornblende-biotite granodiorite. Biotite and hornblende (where present) are generally separate subhedral grains. The amphibole is magnesio-hornblende with average $\mathrm{Fe} / \mathrm{Fe}+\mathrm{Mg}$ ratio of 0.44 (Justino, 1991). The biotite has an av-

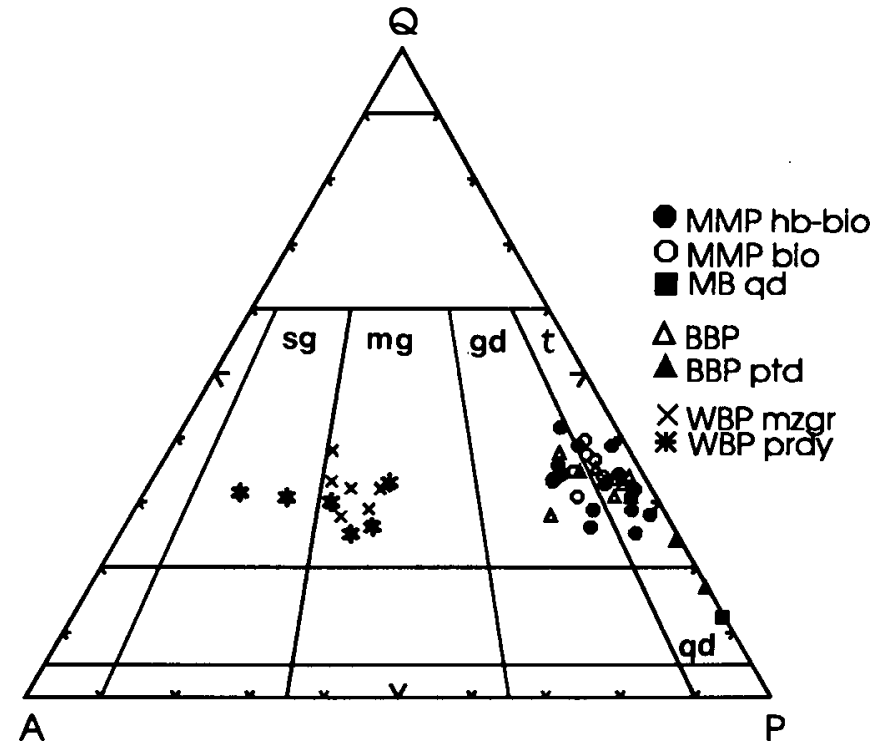

Fig. 2. Plot of modal compositions of samples from the Marble Mountain hornblende-biotite (MMP hb-bio) and biotite (MMP bio) granodiorite units, Mill Brook quartz diorite (MB qd), Big Brook Pluton (BBP) and peripheral tonalite-diorite (BBP ptd), and West Bay monzogranite (WBP mzgr) and porphyry dykes (WBP prdy). Fields on QAP (Quartz-Alkali Feldspar-Plagioclase) diagram are after Streckeisen (1976): $q d=$ quartz diorite; $t=$ tonalite; $g d=$ granodiorite; $\mathrm{mg}=$ monzogranite $; \mathrm{sg}=$ syenogranite

erage $\mathrm{Fe} / \mathrm{Fe}+\mathrm{Mg}$ ratio of 0.51 , and shows only slight variation in composition between the biotite granodiorite and hornblendebiotite granodiorite (Justino, 1991). Accessory minerals include apatite, zircon, titanite, allanite, and opaque minerals; the latter are mainly magnetite, but ilmenite and pyrite are also present. Alteration is generally slight to moderate, and secondary minerals include sericite, saussurite, chlorite, epidote, titanite, muscovite, calcite, and opaque minerals.

\section{Big Brook Pluton}

The Big Brook Pluton consists of relatively homogeneous, white to pale pink, medium-grained hornblende-biotite granodiorite to tonalite (Fig. 2). It is well exposed along major streams, but contacts with surrounding host rocks were not observed and hence its borders are not well defined. The contact with the Lime Hill gneissic complex is inferred to be intrusive, but the pluton is in faulted contact with the Malagawatch Formation. The few enclaves observed in the Big Brook Pluton are typically rounded, small, hornblende-rich, and of dioritic composition. The pluton is cut by rare mafic and granitic dykes, similar to those that cut the Marble Mountain Pluton.

Plagioclase is mostly subhedral with irregular edges; compositions obtained by electron microprobe range from $\mathrm{An}_{52}$ to $\mathrm{An}_{33}$ (Justino, 1991). Quartz forms aggregates of anhedral grains with undulose extinction. Microcline is interstitial, anhedral, and typically poikilitic, enclosing mostly plagioclase grains. Biotite grains are anhedral to subhedral; average $\mathrm{Fe} /$ $\mathrm{Fe}+\mathrm{Mg}$ ratio (0.36; Justino, 1991) is lower than in the Marble Mountain Pluton. Amphibole is commonly less abundant than 
biotite, and varies from irregular anhedral to nearly euhedral grains up to $1 \mathrm{~cm}$ in length. As in the Marble Mountain Pluton, the amphibole is magnesio-hornblende, but average $\mathrm{Fe} / \mathrm{Fe}+\mathrm{Mg}$ ratio (0.36) is lower than in the Marble Mountain Pluton (Justino, 1991). Apatite and opaque minerals are the most common accessory phases; zircon, allanite, and titanite are less common. The dominant opaque mineral is magnetite with minor ilmenite and pyrite. Secondary minerals include sericite, saussurite, chlorite, epidote, titanite, muscovite, calcite, and opaque minerals. All samples display evidence of postintrusional deformation such as undulose extinction in quartz, kinked biotite, and microfractures.

\section{West Bay Pluton}

The West Bay Pluton consists of pink to red, coarse-grained granite, with potassium feldspar megacrysts up to $5 \mathrm{~cm}$ in size. Similar rocks have been exposed by quarrying in the Sugar Camp gypsum quarry $10 \mathrm{~km}$ west of the area shown on Figure 1, and hence the pluton may be much more extensive than shown on Figure 1. The granite is highly fractured and typically disintegrates to gravel-sized, angular fragments. Scattered porphyritic, aplitic, and mafic dykes cut the pluton. Modal compositions of samples from the West Bay Pluton plot in the monzogranite field (Fig. 2). Following Streckeisen (1976), albitized plagioclase was plotted as plagioclase on this diagram, rather than as alkali feldspar.

Both plagioclase and potassium feldspar in the West Bay Pluton are pink due to hematitic staining. Potassium feldspar occurs both as anhedral groundmass grains and as euhedral to subhedral megacrystic grains. Plagioclase is albitized, and analyzed grains give compositions of $\mathrm{Ab}_{99}$ to $\mathrm{Ab}_{92}$ (Justino, 1991). Some grains contain orthogonal inclusions of quartz and exhibit chessboard texture (patchwork albite-twinned grains). Carten (1986) reported similar features where plagioclase had replaced original K-feldspar during hydrothermal alteration.

Quartz forms coarse-grained, irregular masses of interlocking, anhedral phenocrysts with highly sutured grain boundaries. Mafic minerals form between $3 \%$ and $10 \%$ of the rock and have mainly been altered to chlorite. Rare mafic mineral-rich patches about $2 \mathrm{~mm}$ to $10 \mathrm{~mm}$ in diameter may represent relict enclaves. Apatite and zircon are common accessory phases, whereas titanite and allanite are less common. Ilmenite and magnetite are present in a ratio of about $2: 1$; the ilmenite has been completely replaced by secondary phases, but magnetite is mainly unaltered, anhedral, and smaller in size than ilmenite. Pyrite grains are scarce. Alteration is intense throughout the pluton, and all samples show features of post-intrusion deformation such as fractures and undulose extinction in quartz.

Porphyritic dykes in the West Bay Pluton are mineralogically similar to their host rocks, but have hiatal porphyritic textures and are less fractured and altered. K-feldspar is the dominant phenocryst phase. Interstitial granophyre is present in some dykes. Plagioclase grains yield compositions ranging from $A n_{42}$ to $A n_{32}$, and relict amphibole is ferroedenitic hornblende, with a high $\mathrm{Fe} / \mathrm{Fe}+\mathrm{Mg}$ ratio of 0.77 . This ratio is similar to that in biotite in the same sample (Justino, 1991).
Minor plutons

A small body of medium- to coarse-grained tonalite to quartz diorite outcrops at the southwestern end of the Big Brook Pluton. Because of limited outcrop, its boundaries are not well defined; it is assumed to be a peripheral unit possibly related to the Big Brook Pluton. Although similar in appearance to the Big Brook granodiorite/tonalite, it differs in containing less quartz and alkali feldspar, and a higher proportion of mafic minerals (hornblende and biotite).

The Mill Brook quartz diorite intruded rocks of the Malagawatch Formation near the mouth of Mill Brook. It is medium- to coarse-grained and locally porphyritic, with plagioclase phenocrysts. It consists of about $63 \%$ plagioclase, $10 \%$ amphibole, $8 \%$ biotite, and $9 \%$ quartz, with accessory magnetite, apatite, titanite, and allanite.

\section{WHOLE ROCK GEOCHEMISTRY}

Thirty-two samples from the Marble Mountain, Big Brook, West Bay, and associated minor plutons were analyzed for major and trace elements (Tables la, lb). Two samples from each of the Marble Mountain, Big Brook and West Bay plutons also were analyzed for rare-earth elements. Details of analytical methods and petrographic descriptions of analyzed samples are presented in Justino (1991).

\section{Major element data}

The Marble Mountain Pluton shows the largest variation in $\mathrm{SiO}_{2}$ content (62.6 to $72.0 \mathrm{wt}$ \%); the hornblende-biotite granodiorite unit has lower average $\mathrm{SiO}_{2}(66.3 \%)$ than the biotite granodiorite unit $(68.4 \%)$, but higher average $\mathrm{MnO}, \mathrm{K}_{2} \mathrm{O}$, $\mathrm{CaO}, \mathrm{Fe}_{2} \mathrm{O}_{3} \mathrm{t}$, and $\mathrm{MgO}$ (Table la). $\mathrm{SiO}_{2}$ contents in samples from the Big Brook Pluton have a narrow range from 65.3 to $68.9 \mathrm{wt} . \%$, and the average value $(66.2 \%)$ is similar to that in the hornblende-biotite granodiorite unit of the Marble Mountain Pluton. Other major element oxide contents are also generally similar in the two plutons; however, the Big Brook Pluton contains less $\mathrm{TiO}_{2}$ and $\mathrm{P}_{2} \mathrm{O}_{5}$, at a given $\mathrm{SiO}_{2}$ content.

The West Bay monzogranite and associated porphyry dykes have similar average $\mathrm{SiO}_{2}$ contents $(71.2 \mathrm{wt}$. \% and $71.0 \mathrm{wt}$. $\%$, respectively). On average, the monzogranite contains less $\mathrm{CaO}(0.70 \mathrm{wt}$ \%) than the dykes (1.06 wt. \%). This may reflect the albitization of plagioclase in the monzogranite. However, the average $\mathrm{Na}_{2} \mathrm{O}$ contents are nearly the same ( $3.00 \mathrm{wt}$ \%).

In the Marble Mountain Pluton, $\mathrm{Al}_{2} \mathrm{O}_{3}, \mathrm{TiO}_{2}, \mathrm{Fe}_{2} \mathrm{O}_{3} \mathrm{t}$, $\mathrm{MgO}$, and $\mathrm{P}_{2} \mathrm{O}_{5}$ show good negative correlation with $\mathrm{SiO}_{2}(\mathrm{r}=$ -0.70 to -0.98 ; e.g., Fig. 3). In the biotite granodiorite unit, $\mathrm{K}_{2} \mathrm{O}$ and $\mathrm{Na}_{2} \mathrm{O}$ are constant or decrease slightly with increasing $\mathrm{SiO}_{2}$. In contrast, in the hornblende-biotite unit, $\mathrm{K}_{2} \mathrm{O}$ and $\mathrm{Na}_{2} \mathrm{O}$ increase with increasing $\mathrm{SiO}_{2}$. Each unit displays distinct trends (subparallel, with little or no overlap) in $\mathrm{MnO}$ and $\mathrm{TiO}_{2}$, and divergent trends in $\mathrm{K}_{2} \mathrm{O}$, relative to $\mathrm{SiO}_{2}$ (Fig. 3). Although these units may have been derived from very similar or the same source(s), their major element trends indicate somewhat different evolutionary and/or post-emplacement histories. 
The Mill Brook quartz diorite sample plots on the extension of most major element trends in the Marble Mountain Pluton, but a large silica gap separates the quartz diorite from the most mafic sample of the Marble Mountain Pluton (Fig. 3). The relationship, if any, between these units is uncertain.

In the Big Brook Pluton, chemical trends are not well defined because they are based on only five samples, four of which have similar $\mathrm{SiO}_{2}$ contents (Fig. 3). In general, $\mathrm{Al}_{2} \mathrm{O}_{3}, \mathrm{Fe}_{2} \mathrm{O}_{3}$ t, $\mathrm{MgO}, \mathrm{CaO}$, and $\mathrm{P}_{2} \mathrm{O}_{5}$ show strong negative correlation with $\mathrm{SiO}_{2}(\mathrm{r}=-0.84$ to -0.99$) ; \mathrm{K}_{2} \mathrm{O}$ shows positive correlation $(\mathrm{r}=$ 0.96 ), and $\mathrm{Na}_{2} \mathrm{O}$ and $\mathrm{TiO}_{2}$ are poorly correlated with $\mathrm{SiO}_{2}$. The major element trends for the Big Brook Pluton generally overlap those of the hornblende-biotite granodiorite unit of the Marble Mountain Pluton (e.g., Fig. 3), except for $\mathrm{TiO}_{2}$ and $\mathrm{P}_{2} \mathrm{O}_{5}$. The two samples from the peripheral tonalitic to quartz dioritic unit southwest of the $\mathrm{Big}$ Brook Pluton have lower $\mathrm{SiO}_{2}$ contents than the Big Brook samples, but plot along the trends of the Big Brook Pluton and thus may be related to it (Fig. 3).

Major element oxides in the West Bay monzogranite and porphyry dykes generally decrease with increasing $\mathrm{SiO}_{2}$, except $\mathrm{K}_{2} \mathrm{O}$ shows little correlation with $\mathrm{SiO}_{2}$ (Fig. 3). Most of the major element trends in the West Bay samples are clearly separate from those of the Marble Mountain and Big Brook plutons, which suggests that the West Bay Pluton is unrelated to the other plutons.

\section{Trace elements}

The Marble Mountain Pluton has higher average contents of $\mathrm{Zr}$ and $\mathrm{Ba}$ compared to the Big Brook Pluton. The Big Brook Pluton displays positive correlation of $\mathrm{Nb}, \mathrm{Ni}, \mathrm{Rb}, \mathrm{Y}$, and $\mathrm{Zr}$ with $\mathrm{SiO}_{2}(r=0.77$ to 0.98$)$, whereas for the same elements, the Marble Mountain samples show poor to moderate negative correlation $(r=-0.12$ to -0.70$)$. The hornblende-biotite granodiorite of the Marble Mountain Pluton contains significantly higher average $\mathrm{Cu}(31 \mathrm{ppm}$, or $25 \mathrm{ppm}$ if the sample with 71 $\mathrm{ppm}$ is excluded from the average) than the biotite granodiorite (10 ppm).

The West Bay monzogranite and associated porphyry dykes have significantly higher average $\mathrm{Rb}, \mathrm{Ni}, \mathrm{Nb}, \mathrm{Y}, \mathrm{Th}$, and $\mathrm{U}$ contents, moderately higher $\mathrm{Ba}, \mathrm{Pb}$, and $\mathrm{Zr}$, and lower $\mathrm{Sr}$ and $\mathrm{V}$ compared to the granodioritic Marble Mountain and Big Brook plutons, and generally display trends separate from the other plutons on plots of these elements against silica (Justino, 1991). The nickel content in the West Bay samples ( $30 \mathrm{ppm})$ is significantly higher than in average granites, which range from less than $1 \mathrm{ppm}$ to $13 \mathrm{ppm}$ (Whalen et al., 1987); additional analyses are required in order to confirm the accuracy of the Ni analyses.

In all three plutons, Sr shows strong negative correlation with $\mathrm{SiO}_{2}(r=-0.84$ to -0.97$)$, suggesting that plagioclase was a major fractionating phase. In the Marble Mountain hornblende-biotite granodiorite unit and in the Big Brook Pluton, $\mathrm{Ba}$ and $\mathrm{Rb}$ increase with increasing $\mathrm{SiO}_{2}$, implying that biotite and $\mathrm{K}$-feldspar were not important fractionating phases. In contrast, the Marble Mountain biotite granodiorite unit generally displays a decrease in $\mathrm{Ba}$ (Fig. 3) and $\mathrm{Rb}$ with increasing $\mathrm{SiO}_{2}$, which strongly suggests biotite (or less likely K-feldspar) frac- tionation. In the West Bay monzogranite, Ba shows negative correlation (Fig. 3; $r=-0.98$ ) and Rb, positive correlation ( $r=$ 0.95 ), with $\mathrm{SiO}_{2}$. This may have been caused by combined fractionation of plagioclase and either K-feldspar or biotite, or both. Fractionation models for the evolution of the plutons are discussed in more detail below.

Total REE content is highest in the West Bay Pluton and lowest in the Big Brook Pluton (Table 2, Fig. 4). Samples from all three plutons display light REE enrichment and nearly flat heavy REE. Samples with higher $\mathrm{SiO}_{2}$ contents show more fractionated patterns and more prominent negative Eu anomalies (Fig. 4).

\section{Geochemical Modelling}

Granitic rocks have been described as 'mushes' comprised of variable mixtures of cumulate crystals and trapped interstitial melt (McCarthy and Groves, 1979; Tindle and Pearce, 1981). We attempted to model the chemical variations shown by the plutons in the study area by qualitatively determining which mineral phases, if removed from the melt or separated from the crystal mush, would produce the observed chemical trends. Major and large-ion-lithophile (LIL) element trends are compared to calculated fractionation trends, or vectors, for appropriate mineral phases. Calculated major element fractionation trends (and mass balance estimates) were derived by subtracting representative mineral compositions, based on available microprobe data (Justino, 1991) or published data, from an appropriate rock composition. Fractionation vectors for LIL elements were calculated using the equation for Rayleigh fractionation and using appropriate partition coefficients compiled from published data.

\section{Major element modelling}

The possible role of the major mineral phases, plagioclase, hornblende, biotite, and K-feldspar (the latter is a euhedral phase only in the West Bay Pluton), is interpreted graphically using major element oxide plots (Fig. 5a-f), in which general trends in the various units are compared to calculated mineral fractionation trends. Chemical trends are defined by the following sample pairs, which exemplify, in general, the chemical trend in each unit with decreasing $\mathrm{SiO}_{2}$ : Marble Mountain hornblende-biotite granodiorite unit, samples 363 and 195 (trend 1); Marble Mountain biotite granodiorite unit, samples 72 and 378 (trend 2); Big Brook Pluton, samples 394 and 208 (trend 3); West Bay Pluton, samples 257 and 267 (trend 4).

Visual comparison of the chemical trends defined by these samples to the calculated mineral trends (Fig. 5a-f) suggests that in the Marble Mountain hornblende-biotite granodiorite unit and the Big Brook Pluton, plagioclase and hornblende were the dominant fractionating phases; in the Marble Mountain biotite granodiorite unit, biotite was an important fractionating phase; in the West Bay Pluton, plagioclase and biotite are most likely to have been the dominant fractionating phases, whereas $\mathrm{K}$-feldspar does not appear to have been a major fractionating phase.

Mass balance estimates of mineral proportions required to approximate major element trends 1 to $\mathbf{4}$ of selected sample 
Table la. Major elements, trace elements, and normative mineralogy for the Marble Mountain granodiorite and peripheral Mill Brook quartz diorite

Unit: hornblende-biotite granodiorite

Unit: biotite granodiorité

Mill Brook

quartz diorite

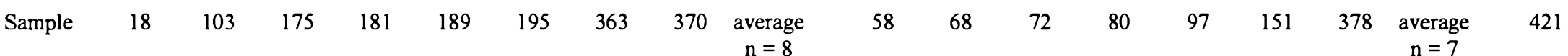

21

Major Elements (wt. \%)

$\begin{array}{lrrrrrrrrr}\mathrm{SiO}_{2} & 66.24 & 62.59 & 64.33 & 67.92 & 65.60 & 70.81 & 64.28 & 68.23 & 66.25 \\ \mathrm{TiO}_{2} & 0.51 & 0.58 & 0.49 & 0.40 & 0.57 & 0.27 & 0.66 & 0.40 & 0.49 \\ \mathrm{Al}_{2} \mathrm{O}_{3} & 15.70 & 16.99 & 16.72 & 15.65 & 16.02 & 15.13 & 16.30 & 15.49 & 16.00 \\ \mathrm{Fe}_{2} \mathrm{O}_{3} \mathrm{t} & 4.68 & 5.39 & 4.44 & 3.58 & 4.27 & 2.16 & 4.94 & 3.45 & 4.11 \\ \mathrm{MnO} & 0.11 & 0.12 & 0.12 & 0.11 & 0.08 & 0.08 & 0.12 & 0.10 & 0.11 \\ \mathrm{MgO} & 1.97 & 2.55 & 2.12 & 1.67 & 2.11 & 1.28 & 2.09 & 1.62 & 1.93 \\ \mathrm{CaO} & 3.43 & 4.17 & 3.67 & 3.03 & 2.91 & 2.17 & 3.72 & 2.78 & 3.24 \\ \mathrm{Na}_{2} \mathrm{O} & 3.82 & 3.84 & 3.97 & 4.03 & 4.74 & 4.14 & 4.01 & 4.16 & 4.09 \\ \mathrm{~K}_{2} \mathrm{O} & 2.07 & 1.75 & 2.00 & 2.07 & 1.85 & 2.51 & 1.76 & 1.56 & 1.95 \\ \mathrm{P}_{2} \mathrm{O}_{5} & 0.15 & 0.15 & 0.15 & 0.12 & 0.17 & 0.08 & 0.18 & 0.12 & 0.14 \\ \mathrm{LOI}_{\mathrm{T}} & 0.90 & 1.60 & 1.70 & 1.10 & 1.30 & 1.00 & 1.70 & 1.10 & 1.30 \\ \mathrm{Total} & 99.58 & 99.73 & 99.71 & 99.68 & 99.62 & 99.63 & 99.76 & 99.01 & 99.59\end{array}$

$\begin{array}{rrrrrrrrc}68.34 & 65.85 & 65.18 & 72.02 & 67.66 & 68.77 & 70.96 & 68.40 & 53.53 \\ 0.56 & 0.70 & 0.54 & 0.41 & 0.46 & 0.47 & 0.35 & 0.50 & 0.73 \\ 15.37 & 15.72 & 16.20 & 13.85 & 16.19 & 15.69 & 14.71 & 15.39 & 18.3 \\ 3.45 & 4.69 & 4.13 & 2.43 & 3.35 & 3.26 & 2.80 & 3.44 & 8.12 \\ 0.08 & 0.07 & 0.09 & 0.06 & 0.09 & 0.05 & 0.06 & 0.07 & 0.13 \\ 1.41 & 2.19 & 1.82 & 1.49 & 1.48 & 1.78 & 1.27 & 1.63 & 4.18 \\ 2.93 & 2.33 & 3.18 & 1.52 & 3.05 & 2.82 & 2.78 & 2.66 & 7.47 \\ 4.23 & 4.55 & 4.27 & 4.27 & 4.48 & 4.26 & 4.21 & 4.32 & 3.45 \\ 1.69 & 1.28 & 1.79 & 1.46 & 1.44 & 1.25 & 1.50 & 1.49 & 0.52 \\ 0.14 & 0.17 & 0.17 & 0.08 & 0.18 & 0.11 & 0.09 & 0.13 & 0.18 \\ 1.10 & 3.30 & 1.70 & 1.50 & 1.10 & 1.40 & 0.08 & 1.45 & 3.1 \\ 99.30 & 100.85 & 99.07 & 99.09 & 99.48 & 99.86 & 98.81 & 99.49 & 99.71\end{array}$

Normative Mineralogy (wt. \%)

$\begin{array}{lrrrrrrrrr}\mathrm{Q} & 25.11 & 19.92 & 22.02 & 27.18 & 21.16 & 30.55 & 22.62 & 29.59 & 24.77 \\ \mathrm{C} & 1.32 & 1.59 & 1.75 & 1.59 & 1.36 & 1.88 & 1.50 & 2.24 & 1.65 \\ \mathrm{Or} & 12.43 & 10.58 & 12.09 & 12.44 & 11.15 & 15.06 & 10.64 & 9.44 & 11.73 \\ \mathrm{Ab} & 32.86 & 33.23 & 34.38 & 34.67 & 40.91 & 35.57 & 34.72 & 36.03 & 35.30 \\ \mathrm{An} & 16.30 & 20.16 & 17.63 & 14.49 & 13.59 & 10.40 & 17.68 & 13.32 & 15.45 \\ \mathrm{Di} & & & & & & & & & \\ \mathrm{Hy} & 8.43 & 10.48 & 8.71 & 6.89 & 8.30 & 4.82 & 8.78 & 6.68 & 7.89 \\ \mathrm{Mt} & 2.21 & 2.56 & 2.11 & 1.69 & 2.02 & 1.02 & 2.35 & 1.64 & 1.95 \\ \mathrm{Il} & 0.99 & 1.13 & 0.95 & 0.77 & 1.10 & 0.52 & 1.28 & 0.78 & 0.94 \\ \mathrm{Ap} & 0.35 & 0.36 & 0.36 & 0.28 & 0.40 & 0.19 & 0.43 & 0.29 & 0.33 \\ & & & & & & & & & \\ \mathrm{D} . \mathrm{I} & 70.40 & 63.73 & 68.49 & 74.29 & 73.22 & 81.18 & 67.98 & 75.06 & 71.79\end{array}$

$\begin{array}{lllllllll}28.88 & 26.07 & 23.86 & 36.60 & 27.32 & 30.40 & 32.73 & 29.41 & 7.87\end{array}$

$\begin{array}{rrrrrrrr}1.62 & 3.11 & 1.92 & 2.74 & 2.19 & 2.51 & 1.34 & 2.20\end{array}$

$\begin{array}{rrrrrrrr}10.19 & 7.78 & 10.89 & 8.86 & 8.67 & 7.52 & 8.99 & 8.99\end{array}$

$\begin{array}{llllllllll}36.53 & 39.59 & 37.21 & 37.08 & 38.62 & 36.69 & 36.15 & 37.41 & 30.39\end{array}$

$\begin{array}{lllllllll}13.90 & 10.75 & 15.10 & 7.20 & 14.22 & 13.51 & 13.40 & 12.58\end{array}$

34.26

$\begin{array}{rrrrrrrrr}5.82 & 8.70 & 7.58 & 5.37 & 6.08 & 6.67 & 5.18 & 6.49 & 16.08\end{array}$

$\begin{array}{lllllllll}1.63 & 2.24 & 1.97 & 1.16 & 1.58 & 1.54 & 1.32 & 1.63 & 3.80\end{array}$

$\begin{array}{lllllllll}1.09 & 1.37 & 1.06 & 0.80 & 0.89 & 0.91 & 0.68 & 0.97 & 1.44\end{array}$

$\begin{array}{lllllllll}0.33 & 0.41 & 0.41 & 0.19 & 0.43 & 0.26 & 0.21 & 0.32 & 0.43\end{array}$

D.I

$\begin{array}{llllllll}75.60 & 73.44 & 71.96 & 82.54 & 74.61 & 74.61 & 77.87 & 75.80\end{array}$

41.46

Trace Elements (ppm)

$\begin{array}{lrrrrrrrrr}\mathrm{B} & 50 & 24 & 32 & 18 & 145 & 35 & 32 & 18 & 44 \\ \mathrm{Ba} & 350 & 375 & 387 & 553 & 505 & 639 & 550 & 424 & 473 \\ \mathrm{Cu} & 29 & 37 & 71 & 22 & 24 & 13 & 21 & 28 & 31 \\ \mathrm{Cr} & 19 & 26 & 23 & 24 & 25 & 26 & 25 & 34 & 25 \\ \mathrm{Ga} & 16 & 17 & 18 & 18 & 18 & 16 & 16 & 17 & 17 \\ \mathrm{Mo} & 3 & 2 & 2 & 3 & 7 & 3 & 3 & 3 & 3\end{array}$

$\begin{array}{rrrrrrrrr}31 & 33 & 18 & 30 & 32 & 31 & 13 & 27 & 19 \\ 631 & 109 & 566 & 321 & 526 & 366 & 408 & 418 & 68 \\ 18 & 5 & 18 & 6 & 8 & 11 & 3 & 10 & 36 \\ 25 & 20 & 20 & 26 & 27 & 28 & 41 & 27 & 32 \\ 17 & 19 & 19 & 14 & 18 & 15 & 15 & 17 & 21 \\ 5 & 4 & 4 & 3 & 4 & 3 & 4 & 4 & 3\end{array}$




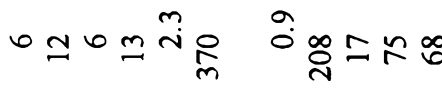

$$
\begin{aligned}
& \text { oㅅ } \\
& \infty-\exists \stackrel{\infty}{\sim} \underset{\sim}{\tilde{N}} \backsim \stackrel{n}{m} \backsim m \tilde{q}
\end{aligned}
$$

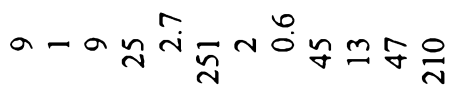

$$
\begin{aligned}
& \text { ㄱกำ }
\end{aligned}
$$

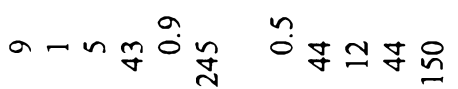

$$
\begin{aligned}
& ==m \text { 골 }
\end{aligned}
$$

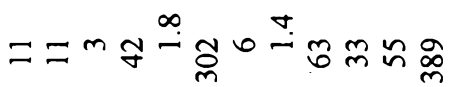

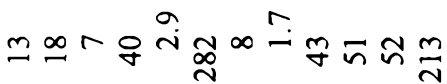

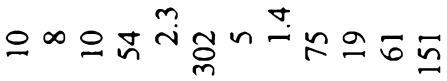

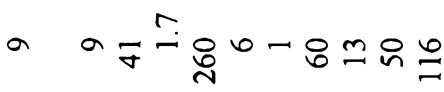

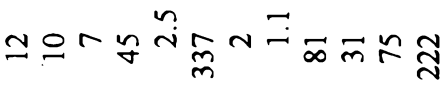

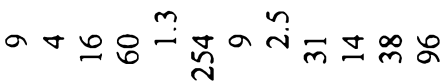

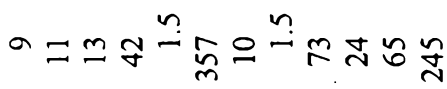

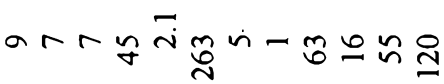

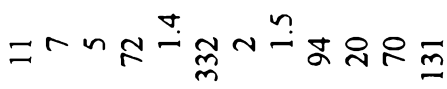

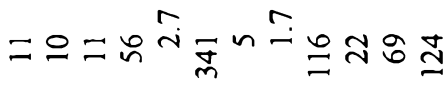

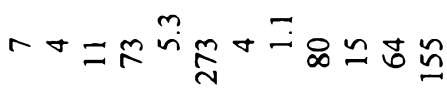

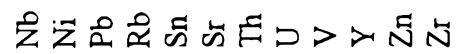

pairs (parent-daughter compositions) in the various units are listed in Table 3 . These estimates were derived by adjusting least-square mixing estimates to the observed trends by using spreadsheet programs with graphic capabilities. Results indicate that removal of primarily plagioclase and hornblende at 2:1 ratio, and minor biotite, approximates the major element variation exhibited by the Marble Mountain hornblende-biotite granodiorite (trend 1). In contrast, major element variation in the Marble Mountain biotite granodiorite (trend 2) can be attributed to fractionation dominated by plagioclase and biotite at 2:1 ratio. Estimates for the Big Brook Pluton indicate possible fractionation dominated by plagioclase and hornblende at 1.8:1 ratio and little or no biotite removal; the results are similar to those for the hornblende-biotite granodiorite unit of the Marble Mountain Pluton. Mass balance estimates of the major element variation in the West Bay Pluton (trend 4) can be attributed to fractionation dominated by plagioclase and biotite at 2.8:1 ratio and minor hornblende. Using $\mathrm{K}$-feldspar as a fractionating phase in mass balance calculations for the West Bay Pluton did not produce reasonable results, and hence it was not used in the calculations.

\section{Large-ion-lithophile (LIL) element modelling}

Because LIL elements occur mainly in major minerals, they can be used to model the major fractionating phases (Tindle and Pearce, 1981). In plots involving $\mathrm{Sr}, \mathrm{Rb}$, and $\mathrm{Ba}$ (Fig. 6ad), we compare the observed LIL variations in the various units with calculated mineral fractionation vectors and with mass balance trends: the latter were constructed with major mineral ratios and degree of fractionation derived from the mass balance calculations.

Compared to calculated mineral vectors, the LIL variations in the Marble Mountain hornblende-biotite granodiorite and in the Big Brook Pluton, which are nearly parallel, agree with fractionation dominated by plagioclase and hornblende. In the Marble Mountain biotite granodiorite, LIL variations indicate primarily plagioclase and biotite fractionation (Fig. 6a, b). The LIL trends in the Marble Mountain units and the Big Brook Pluton show good agreement with mass balance vectors (trends 1 to 3), except in magnitude.

LIL variations in the West Bay monzogranite and porphyry dykes are compared to calculated mineral fractionation vectors and the mass balance vector (trend 4) (Fig. 6c, d). Because of large variations in partition coefficient values in evolved magmas, the mineral fractionation vectors were constructed using both low and high partition coefficients from silicic magmas (Nash and Crecraft, 1985); mass balance vector 4 was constructed with low partition coefficients only. Compared to mineral vectors, observed LIL variations in the West Bay monzogranite appear to have been dominated by plagioclase \pm biotite $\pm \mathrm{K}$-feldspar fractionation, whereas mass balance calculations suggest plagioclase, biotite, and possibly minor hornblende as fractionating phases. Considering uncertainties in partition coefficients, the mass balance vector (trend 4 ) generally agrees with observed LIL variations, except in magnitude. 
Table lb. Major elements, trace elements, and normative mineralogy for the Big Brook granodiorite and peripheral quartz diorite; and West Bay monzogranite and porphry dykes

Pluton: Big Brook

Unit: hornblende-biotite granodiorite

19

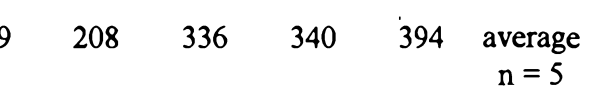

Unit: quartz diorite to Unit: monzogranite

tonalite peripheral to

the Big Brook pluton

Pluton: West Bay

$500 \quad 501$

$257 \quad 267 \quad 285$
Unit: porphyry and granophyric dykes

$\begin{array}{lllll}268 & 290 & 316 & 591 & \text { average }\end{array}$
Major Elements (wt. \%)

$\begin{array}{lrrrrrr}\mathrm{SiO}_{2} & 65.27 & 68.86 & 65.80 & 65.33 & 65.64 & 66.18 \\ \mathrm{TiO}_{2} & 0.34 & 0.32 & 0.29 & 0.33 & 0.31 & 0.32 \\ \mathrm{Al}_{2} \mathrm{O}_{3} & 16.01 & 14.89 & 16.18 & 16.56 & 15.90 & 15.91 \\ \mathrm{Fe}_{2} \mathrm{O}_{3} \mathrm{t} & 4.40 & 3.48 & 3.86 & 4.11 & 4.32 & 4.03 \\ \mathrm{MnO} & 0.11 & 0.10 & 0.11 & 0.11 & 0.14 & 0.11 \\ \mathrm{MgO} & 2.32 & 1.66 & 2.06 & 2.24 & 2.40 & 2.14 \\ \mathrm{CaO} & 3.37 & 2.54 & 3.70 & 4.32 & 4.12 & 3.61 \\ \mathrm{Na}_{2} \mathrm{O} & 3.88 & 3.78 & 3.53 & 3.76 & 3.49 & 3.69 \\ \mathrm{~K}_{2} \mathrm{O} & 1.93 & 2.86 & 1.95 & 1.87 & 1.69 & 2.06 \\ \mathrm{P}_{2} \mathrm{O}_{5} & 0.11 & 0.09 & 0.11 & 0.11 & 0.11 & 0.11 \\ \mathrm{LOI} & 2.20 & 1.40 & 1.70 & 0.90 & 1.40 & 1.52 \\ \text { Total } & 99.24 & 99.98 & 99.29 & 99.64 & 99.52 & 99.67\end{array}$

Normative Mineralogy (wt. \%)

$\begin{array}{lrrrrrr}\mathrm{Q} & 24.01 & 27.52 & 26.44 & 22.92 & 25.76 & 25.33 \\ \mathrm{C} & 1.72 & 1.19 & 1.85 & 0.77 & 1.13 & 1.33 \\ \mathrm{Or} & 11.70 & 17.18 & 11.84 & 11.22 & 10.21 & 12.43 \\ \mathrm{Ab} & 33.69 & 32.52 & 30.69 & 32.31 & 30.18 & 31.88 \\ \mathrm{An} & 16.42 & 12.21 & 18.12 & 21.04 & 20.16 & 17.59 \\ \mathrm{Di} & & & & & & \\ \mathrm{Hy} & 9.44 & 6.90 & 8.40 & 8.91 & 9.65 & 8.66 \\ \mathrm{Mt} & 2.10 & 1.64 & 1.84 & 1.94 & 2.05 & 1.91 \\ \mathrm{II} & 0.66 & 0.62 & 0.57 & 0.64 & 0.60 & 0.62 \\ \mathrm{Ap} & 0.26 & 0.21 & 0.26 & 0.26 & 0.26 & 0.25\end{array}$

$\begin{array}{rr}60.83 & 56.33 \\ 0.53 & 0.77 \\ 16.59 & 17.38 \\ 6.40 & 8.23 \\ 0.15 & 0.20 \\ 3.21 & 3.53 \\ 5.03 & 5.72 \\ 3.23 & 3.75 \\ 1.60 & 1.27 \\ 0.12 & 0.23 \\ 1.60 & 1.80 \\ 99.29 & 99.21\end{array}$

$\begin{array}{rrrrrr}69.52 & 72.13 & 71.70 & 69.30 & 73.41 & 71.21 \\ 0.55 & 0.30 & 0.40 & 0.53 & 0.31 & 0.42 \\ 14.07 & 12.98 & 13.96 & 14.17 & 13.19 & 13.67 \\ 4.12 & 2.37 & 3.14 & 3.77 & 2.88 & 3.26 \\ 0.06 & 0.04 & 0.06 & 0.05 & 0.05 & 0.05 \\ 1.09 & 0.82 & 0.85 & 1.00 & 0.94 & 0.94 \\ 0.99 & 0.40 & 0.69 & 1.11 & 0.33 & 0.70 \\ 3.22 & 2.90 & 2.94 & 3.14 & 2.82 & 3.00 \\ 4.82 & 5.28 & 5.02 & 4.85 & 4.74 & 4.94 \\ 0.14 & 0.07 & 0.10 & 0.14 & 0.07 & 0.10 \\ 1.20 & 1.10 & 0.09 & 1.90 & 1.00 & 1.06 \\ 99.78 & 98.39 & 98.95 & 99.96 & 99.74 & 99.36\end{array}$

$18.99 \quad 10.31$$$
0.71
$$

$9.72 \quad 7.75$

$28.10 \quad 32.76$

$24.85 \quad 27.71$

0.03
$13.26 \quad 15.44$

$\begin{array}{rr}13.26 & 15.44 \\ 3.05 & 3.94\end{array}$

$1.04 \quad 1.51$

$0.29 \quad 0.55$

$56.81 \quad 50.82$ $\begin{array}{rrrrrr}28.60 & 33.61 & 32.67 & 28.85 & 36.81 & 32.11\end{array}$

$\begin{array}{llllll}2.13 & 1.99 & 2.71 & 2.12 & 3.03 & 2.40\end{array}$

$\begin{array}{rrrrrr}28.96 & 32.11 & 30.06 & 29.29 & 28.41 & 29.77\end{array}$

$\begin{array}{lllllll}27.71 & 25.26 & 25.21 & 27.16 & 24.21 & 25.91\end{array}$

$\begin{array}{llllll}4.06 & 1.57 & 2.81 & 4.69 & 1.20 & 2.87\end{array}$

$\begin{array}{llllll}4.72 & 3.28 & 3.69 & 4.29 & 3.88 & 3.97\end{array}$

$\begin{array}{llllll}2.43 & 1.42 & 1.85 & 2.24 & 1.69 & 1.92\end{array}$

$\begin{array}{llllll}1.06 & 0.59 & 0.77 & 1.03 & 0.60 & 0.81\end{array}$

$\begin{array}{llllll}0.33 & 0.17 & 0.24 & 0.33 & 0.17 & 0.25\end{array}$

$\begin{array}{lllll}85.27 & 90.98 & 87.94 & 85.30 & 89.43\end{array}$

$\begin{array}{rrrrr}69.66 & 69.05 & 70.71 & 74.50 & 70.98 \\ 0.53 & 0.60 & 0.42 & 0.24 & 0.45 \\ 13.80 & 13.93 & 14.12 & 13.02 & 13.72 \\ 3.58 & 4.22 & 3.16 & 1.93 & 3.22 \\ 0.07 & 0.06 & 0.06 & 0.04 & 0.06 \\ 0.88 & 0.97 & 0.82 & 0.65 & 0.83 \\ 1.63 & 1.52 & 0.85 & 0.25 & 1.06 \\ 3.01 & 2.97 & 3.09 & 2.81 & 2.97 \\ 5.22 & 4.69 & 5.46 & 5.30 & 5.17 \\ 0.12 & 0.15 & 0.09 & 0.05 & 0.10 \\ 0.06 & 1.70 & 0.90 & 0.90 & 0.89 \\ 98.56 & 99.86 & 99.68 & 99.69 & 99.45\end{array}$

$\begin{array}{lllll}27.45 & 29.29 & 28.77 & 36.56 & 30.52\end{array}$ $\begin{array}{lllll}0.53 & 1.60 & 1.82 & 2.36 & 1.58\end{array}$ $\begin{array}{lllll}31.38 & 28.30 & 32.72 & 31.74 & 31.04\end{array}$ $\begin{array}{lllll}25.91 & 25.67 & 26.52 & 24.09 & 25.55\end{array}$ $\begin{array}{lllll}7.43 & 6.70 & 3.68 & 0.93 & 4.68\end{array}$

$\begin{array}{lllll}3.88 & 4.42 & 3.60 & 2.61 & 3.63\end{array}$

$\begin{array}{lllll}2.11 & 2.50 & 1.86 & 1.13 & 1.90\end{array}$

$\begin{array}{lllll}1.02 & 1.16 & 0.81 & 0.46 & 0.86\end{array}$

$\begin{array}{lllll}0.28 & 0.36 & 0.21 & 0.12 & 0.24\end{array}$

$\begin{array}{llll}84.74 & 83.26 & 88.01 & 92.39\end{array}$

Trace Elements (ppm)

$\begin{array}{lrrrrrrrrrrrrrrrrrrr}\mathrm{B} & 32 & 12 & 20 & 29 & 57 & 30 & 20 & 23 & 34 & 8 & 23 & 23 & 23 & 30 & 16 & 23 & 74 \\ \mathrm{Ba} & 281 & 347 & 343 & 372 & 253 & 319 & 317 & 217 & 802 & 563 & 668 & 777 & 529 & 668 & 692 & 606 & 708 & 756 & 691 \\ \mathrm{Cu} & 11 & 6 & 9 & 10 & 13 & 10 & 30 & 32 & 1 & 10 & 9 & 14 & 2 & 7 & 5 & 14 & 6 & 8 & 8\end{array}$




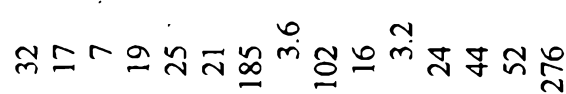
$\stackrel{\sim}{\sim}=$ ニニ요

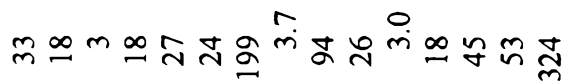

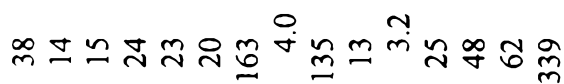

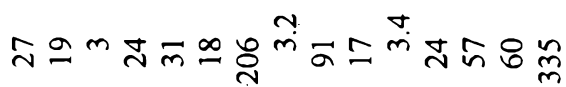

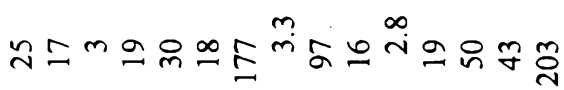

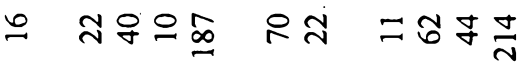

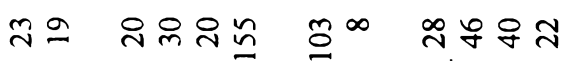

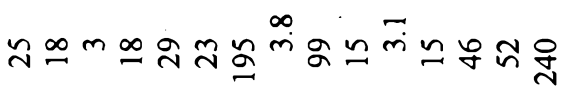

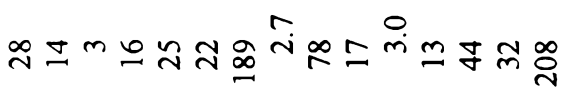

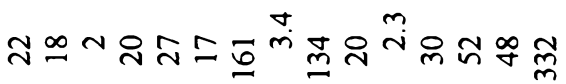
মNㄲ

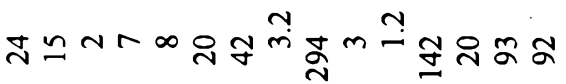

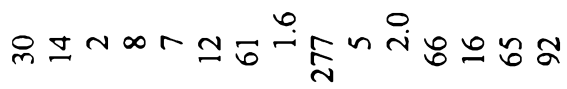

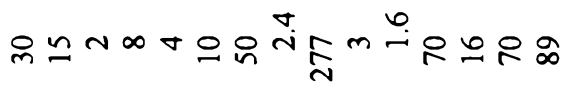

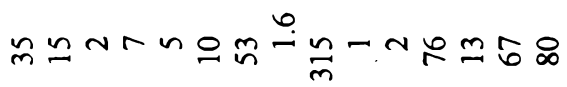

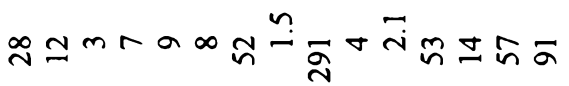
누

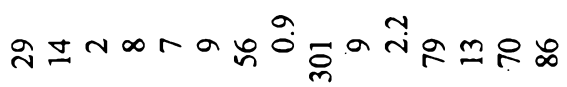

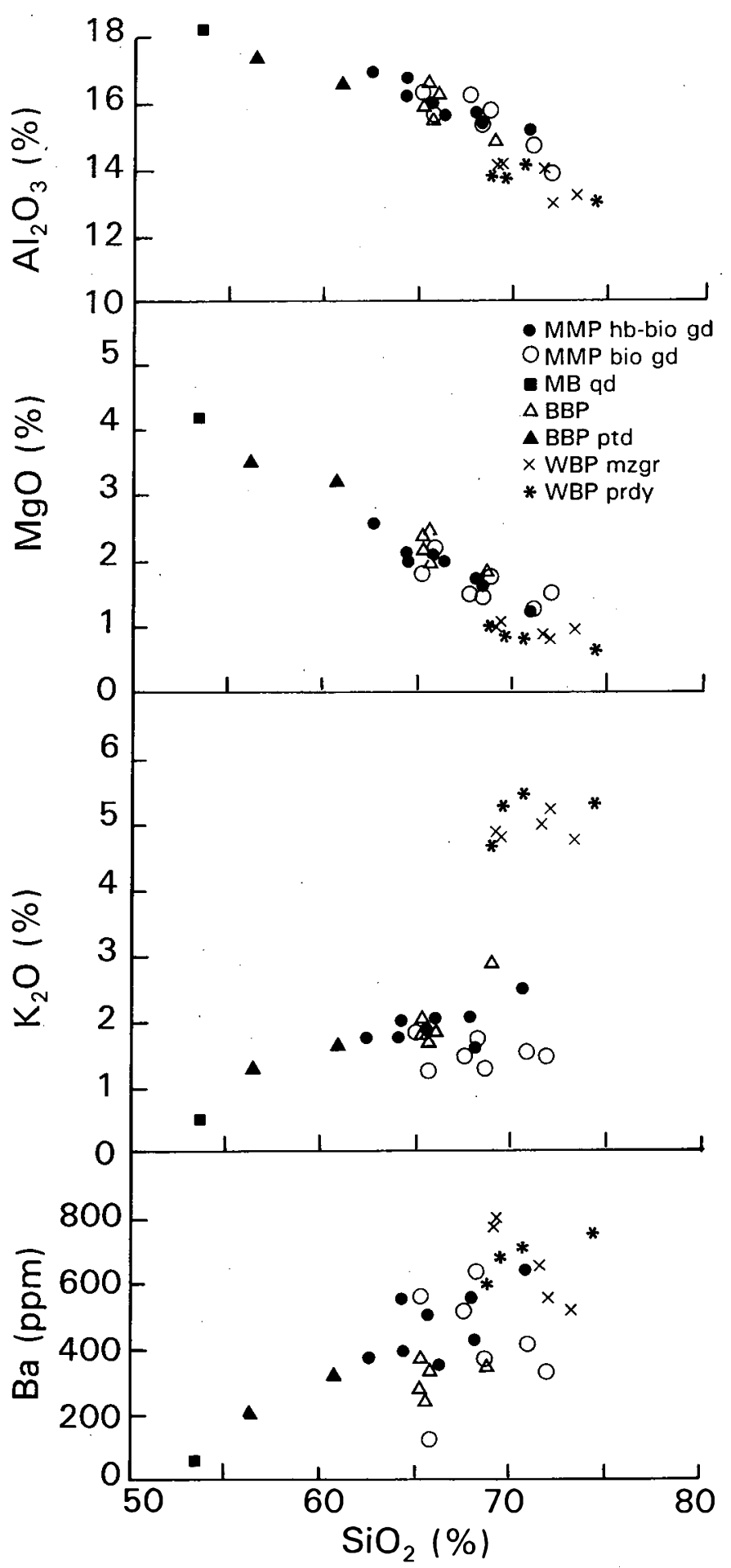

Fig. 3. Selected silica variation diagrams to illustrate chemical trends in the hornblende-biotite granodiorite (MMP hb-bio gd) and biotite granodiorite (MMP bio gd) units of the Marble Mountain Pluton, Mill Brook quartz diorite (MB qd), Big Brook Pluton (BBP), peripheral tonalite/quartz diorite (BBP ptd), and monzogranite (WBP mzgr) and porphyritic dykes (WBP prdy) of the West Bay Pluton. Data are from Table 1. Variation diagrams for other elements are shown by Justino (1991). 
Table 2. Rare-earth element (REE) data for the Marble Mountain, Big Brook, and West Bay plutons

\begin{tabular}{lcccccc}
\hline & $\begin{array}{l}\text { Marble Mountain pluton } \\
\text { hornblende-biotite unit }\end{array}$ & Big Brook pluton & West Bay pluton \\
& & & & & & \\
\hline & & & & & & \\
Sample \# & 103 & 189 & 340 & 208 & 257 & 267 \\
$\mathrm{SiO}_{2}$ wt. \% & 62.59 & 65.60 & 65.33 & 68.86 & 69.52 & 72.13 \\
& & & & & & \\
$\mathrm{REE}(\mathrm{ppm})$ & & & & & & \\
$\mathrm{La}$ & 16.7 & 59.3 & 9.8 & 18.5 & 41 & 93.5 \\
$\mathrm{Ce}$ & 33 & 91 & 16 & 31 & 87 & 125 \\
$\mathrm{Nd}$ & 18 & 35 & 6 & 14 & 35 & 46 \\
$\mathrm{Sm}$ & 4.09 & 6.22 & 1.83 & 3.28 & 7.86 & 8.31 \\
$\mathrm{Eu}$ & 1.03 & 0.73 & 0.77 & 0.65 & 1.16 & 2.16 \\
$\mathrm{~Tb}$ & 0.6 & 0.7 & 0.3 & 0.4 & 2.1 & 1.1 \\
$\mathrm{Yb}$ & 2.19 & 2.42 & 1.01 & 2.66 & 5.37 & 4.6 \\
$\mathrm{Lu}$ & 0.41 & 0.44 & 0.23 & 0.51 & 0.94 & 0.81 \\
& & & & & & \\
$\mathrm{La} / \mathrm{Yb}$ & 5.10 & 16.39 & 6.49 & 4.65 & 5.11 & 13.59 \\
$\mathrm{La} / \mathrm{Sm}$ & 2.52 & 5.88 & 3.30 & 3.48 & 3.22 & 6.94 \\
$\mathrm{~Tb} / \mathrm{Yb}$ & 1.16 & 1.22 & 1.26 & 0.64 & 1.65 & 1.01 \\
$\mathrm{Eu} / \mathrm{Eu} *$ & 0.79 & 0.39 & 1.28 & 0.65 & 0.38 & 0.84 \\
& & & & & & \\
\hline
\end{tabular}

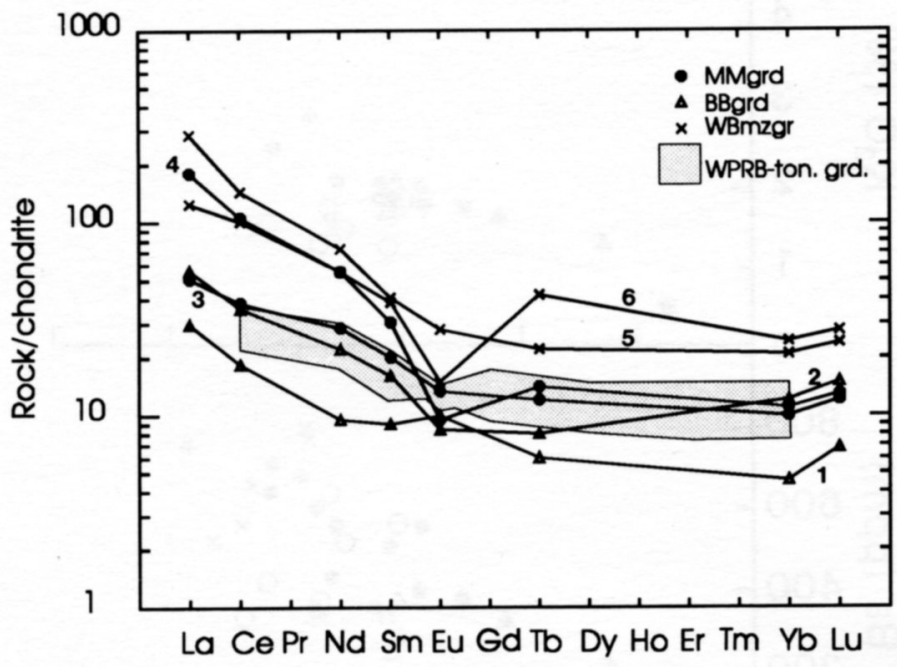

Fig. 4. Chondrite-normalized rare-earth element plot for samples from the Marble Mountain hornblende-biotite granodiorite (MMgrd), Big Brook granodiorite (BBgrd), and West Bay monzogranite (WBmzgr). Shaded field for tonalite and granodiorite from the western part of the Peninsular Ranges Batholith (WPRB) is from Gromet and Silver (1987). Chondrite normalizing values are from Wheatley and Rock (1988). Data are from Table 2; $1=340,2=208,3=103,4=189,5=$ $257,6=267$.

\section{$\mathrm{Ti}, \mathrm{Mn}, \mathrm{P}, \mathrm{Zr}, \mathrm{Nb}$, and $\mathrm{Y}$ variations}

Mass balance estimates implied minor magnetite, ilmenite, and apatite fractionation in all units (Table 3). Graphically, magnetite fractionation is difficult to assess relative to other Febearing phases. However, if plagioclase is a major fractionat- ing phase, then the large decrease in $\mathrm{FeOt}+\mathrm{MgO}$ (Fig. 5b) cannot be attributed solely to hornblende \pm biotite removal. $\mathrm{MnO}$ $\mathrm{TiO}_{2}$ plots (Fig. 5c, f) show that except for the Big Brook Pluton, the units display large decrease in $\mathrm{TiO}_{2}$ relative to $\mathrm{MnO}$. This implies some noticeable degree of biotite $\pm \mathrm{Fe}$-Ti oxide fractionation. All units display decreasing $\mathrm{P}_{2} \mathrm{O}_{5}$ with increasing $\mathrm{SiO}_{2}$, which implies apatite fractionation.

$\mathrm{Zr}, \mathrm{Nb}$, and $\mathrm{Y}$ are generally considered incompatible elements and hence are concentrated in residual magmas. The Big Brook Pluton is the only unit in which these elements increase with increasing $\mathrm{SiO}_{2}$. In both units of the Marble Mountain Pluton these elements display an initial slight increase and subsequent moderate decrease. The West Bay Pluton shows substantial decrease in $\mathrm{Zr}$ and $\mathrm{Nb}$, and moderate decrease in $\mathrm{Y}$, with increasing $\mathrm{SiO}_{2}$. Using the work of Pearce and Norry (1979) on the variations of $\mathrm{Zr}, \mathrm{Y}$, and $\mathrm{Nb}$ in volcanic rocks, these trends are interpreted in the following manner: fractionation dominated by plagioclase and hornblende at a ratio of approximately $2: 1$, as in the Big Brook Pluton, concentrates these elements in the melt (trend 3, Pearce and Norry, 1979); fractionation dominated by plagioclase, hornblende, and biotite \pm zircon produces a decrease in all three elements (trend 5, Pearce and Norry, 1979).

\section{Discussion}

The major element and LIL variations observed in the Marble Mountain and Big Brook plutons can be modeled by liquid-solid fractionation processes involving the mineral phases estimated from mass balance calculations. Data from the Marble Mountain biotite granodiorite display the greatest amount of 

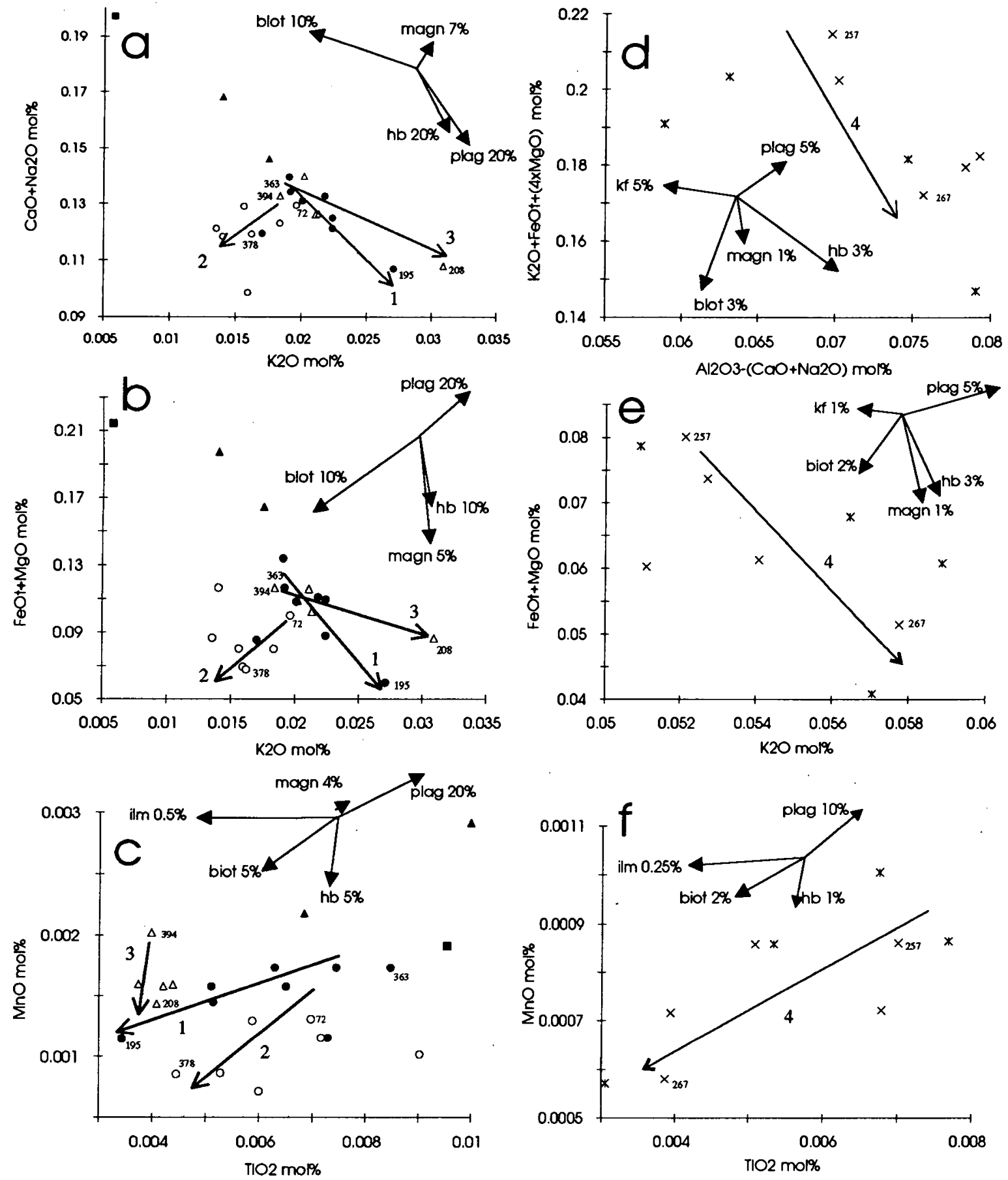

Fig. 5. Selected major oxide plots for Marble Mountain and Big Brook plutons (a, b, c) and West Bay Pluton (d, e, f); symbols as in Figure 2. Trends 1 (Marble Mountain hormblende-biotite granodiorite), 2 (Marble Mountain biotite granodiorite), 3 (Big Brook Pluton), and 4 (West Bay Pluton) are derived as explained in text. Calculated mineral fractionation trends are for the following mineral phases: plagioclase (plag), hornblende (hb), biotite (biot), magnetite (magn), ilmenite (ilm), and K-feldspar (kf), using compositions obtained by electron microprobe (Justino, 1991). Mineral fractionation trends apply strictly only to a single point: 363 for Marble Mountain and Big Brook plutons and 257 for West Bay Pluton. However, they do not change significantly for the restricted compositional variation in the samples of interest.

scatter, possibly reflecting incomplete separation of crystals and residual liquid. Alternatively, the biotite granodiorite is also the only unit with a large number of country rock xenoliths, and the higher degree of scatter may reflect contamination.

Major element variation in the West Bay monzogranite can be attributed to fractionation dominated by plagioclase and biotite and minor hornblende, magnetite, ilmenite and apatite.
However, fractional crystallization cannot be distinguished from equilibrium fractionation (or partial melting) for a suite of rocks (a) that displays restricted compositional range (i.e., small degrees of fractionation), (b) for which partition coefficients are not well known, and (c) for which fractionating mafic and opaque phases are not adequately estimated. Hence, because of its restricted compositional range and felsic nature, it is un- 
Table 3. Mass balance calculations for selected sample pairs in the Marble Mountain, Big Brook, and West Bay plutons

\begin{tabular}{|c|c|c|c|c|c|c|c|c|c|c|c|c|c|}
\hline \multirow[t]{2}{*}{ Unit: } & \multicolumn{6}{|c|}{ Marble Mountain hornblende-biotite granodiorite } & \multirow[t]{2}{*}{ Unit: } & \multicolumn{6}{|c|}{ Marble Mountain biotite granodiorite } \\
\hline & \multirow{2}{*}{$\begin{array}{r}\text { Parent } \\
363\end{array}$} & \multirow{2}{*}{$\begin{array}{r}\text { Daughter } \\
195\end{array}$} & \multirow{2}{*}{$\begin{array}{c}\text { Calculated } \\
\text { Daughter }\end{array}$} & \multicolumn{3}{|c|}{ Total Cumulate } & & Parent & Daughter & \multirow{2}{*}{$\begin{array}{l}\text { Calculated } \\
\text { Daughter }\end{array}$} & \multicolumn{3}{|c|}{ Total Cumulate } \\
\hline Sample & & & & $25 \%$ & & & Sample & 72 & 378 & & $25 \%$ & & \\
\hline $\mathrm{SiO} 2$ & 65.88 & 71.95 & 71.31 & & & & $\mathrm{SiO} 2$ & 67.23 & 72.08 & 72.81 & & & \\
\hline $\mathrm{TiO} 2$ & 0.68 & 0.27 & 0.37 & Mineral \% & & Ratios & $\mathrm{TiO} 2$ & 0.56 & 0.36 & 0.33 & Mineral \% & & latios \\
\hline $\mathrm{Al} 2 \mathrm{O} 3$ & 16.71 & 15.37 & 16.25 & & & $\mathrm{X} / \mathrm{Hb}$ & $\mathrm{Al} 2 \mathrm{O} 3$ & 16.71 & 14.94 & 14.91 & & & Biot \\
\hline $\mathrm{FeO}$ & 4.56 & 1.98 & 2.13 & Plag & 14.65 & 2.06 & $\mathrm{FeO}$ & 3.83 & 2.56 & 2.43 & Plag & 16.20 & 1.96 \\
\hline $\mathrm{MnO}$ & 0.12 & 0.08 & 0.05 & $\mathrm{Hb}$ & 7.12 & 1.00 & $\mathrm{MnO}$ & 0.09 & 0.06 & 0.04 & $\mathrm{Hb}$ & 0.00 & 0.00 \\
\hline $\mathrm{MgO}$ & 2.14 & 1.30 & 1.53 & Biot & 1.19 & 0.17 & $\mathrm{MgO}$ & 1.88 & 1.29 & 1.23 & Biot & 8.28 & 1.00 \\
\hline $\mathrm{CaO}$ & 3.81 & 2.20 & 2.23 & Apatite & 0.26 & 0.04 & $\mathrm{CaO}$ & 3.28 & 2.82 & 2.51 & Apatite & 0.25 & 0.03 \\
\hline $\mathrm{Na} 2 \mathrm{O}$ & 4.11 & 4.21 & 3.89 & Magnetite & 1.23 & 0.17 & $\mathrm{Na} 2 \mathrm{O}$ & 4.40 & 4.28 & 4.23 & Magnetite & 0.20 & 0.02 \\
\hline $\mathrm{K} 2 \mathrm{O}$ & 1.80 & 2.55 & 2.15 & Ilmenite & 0.55 & 0.08 & $\mathrm{~K} 2 \mathrm{O}$ & 1.85 & 1.52 & 1.40 & Ilmenite & 0.07 & 0.01 \\
\hline P2O5 & 0.18 & 0.08 & 0.10 & & & & P2O5 & 0.18 & 0.09 & 0.09 & & & \\
\hline \multirow[t]{2}{*}{ Unit: } & \multicolumn{6}{|c|}{ Big Brook granodiorite } & Unit: & \multicolumn{6}{|c|}{ West Bay monzogranite } \\
\hline & Parent & Daughter & Calculated & Total Cumu & & & & Parent & Daughter & Calculated & Total Cumı & & \\
\hline Sample & 394 & 208 & Daughter & $20 \%$ & & & Sample & 257 & 267 & Daughter & $12 \%$ & & \\
\hline $\mathrm{SiO} 2$ & 67.19 & 70.10 & 70.73 & & & & $\mathrm{SiO} 2$ & 70.82 & 74.32 & 74.04 & & & \\
\hline $\mathrm{TiO} 2$ & 0.32 & 0.33 & 0.30 & Mineral \% & & Ratios & $\mathrm{TiO} 2$ & 0.56 & 0.31 & 0.33 & Mineral \% & & Ratios \\
\hline $\mathrm{Al} 2 \mathrm{O} 3$ & 16.28 & 15.16 & 15.66 & & & $\mathbf{X} / \mathrm{Hb}$ & $\mathrm{Al} 2 \mathrm{O} 3$ & 14.33 & 13.37 & 13.58 & & & E/Biot \\
\hline $\mathrm{FeO}$ & 3.98 & 3.19 & 3.20 & Plag & 12.50 & 1.80 & $\mathrm{FeO}$ & 3.78 & 2.20 & 2.21 & Plag & 7.56 & 2.79 \\
\hline $\mathrm{MnO}$ & 0.14 & 0.10 & 0.08 & $\mathrm{Hb}$ & 6.94 & 1.00 & $\mathrm{MnO}$ & 0.06 & 0.04 & 0.05 & $\mathrm{Hb}$ & 0.56 & 0.21 \\
\hline $\mathrm{MgO}$ & 2.46 & 1.69 & 1.85 & Biot & 0.00 & 0.00 & $\mathrm{MgO}$ & 1.11 & 0.84 & 1.08 & Biot & 2.71 & 1.00 \\
\hline $\mathrm{CaO}$ & 4.22 & 2.59 & 2.78 & Apatite & 0.10 & 0.01 & $\mathrm{CaO}$ & 1.01 & 0.41 & 0.31 & Apatite & 0.17 & 0.06 \\
\hline $\mathrm{Na} 2 \mathrm{O}$ & 3.57 & 3.85 & 3.24 & Magnetite & 0.40 & 0.06 & $\mathrm{Na} 2 \mathrm{O}$ & 3.28 & 2.99 & 3.07 & Magnetite & 0.71 & 0.26 \\
\hline $\mathrm{K} 2 \mathrm{O}$ & 1.73 & 2.91 & 2.09 & Ilmenite & 0.06 & 0.01 & $\mathrm{~K} 2 \mathrm{O}$ & 4.91 & 5.44 & 5.25 & nmenite & 0.29 & 0.11 \\
\hline $\mathrm{P} 205$ & 0.11 & 0.09 & 0.09 & & & & P2O5 & 0.14 & 0.07 & 0.08 & & & \\
\hline
\end{tabular}

Mineral compositions were taken from microprobe data (Justino, 1991) or representative published data.

clear whether the samples of the West Bay monzogranite are related by fractional or equilibrium crystallization of plagioclase and biotite, or represent variable partial melting leaving a residue consisting primarily of plagioclase and biotite. In any case, the extensive alteration in the pluton indicates that caution should be used in interpreting chemical variations.

\section{GRANITOID CLASSIFICATION AND TECTONIC SETTING}

On an AFM diagram (Fig. 7), the Marble Mountain and Big Brook plutons have overlapping calc-alkalic trends, whereas the West Bay Pluton displays a separate trend at lower $\mathrm{MgO}$ content. The average $\mathrm{Al}_{2} \mathrm{O}_{3} /\left(\mathrm{CaO}+\mathrm{Na}_{2} \mathrm{O}+\mathrm{K}_{2} \mathrm{O}\right)$ ratios in all three plutons are slightly more than 1 (Marble Mountain hornblende-biotite and biotite granodiorite units: 1.09 and 1.14, respectively; Big Brook Pluton: 1.08; West Bay Pluton and porphyry dykes: 1.18 and 1.13 , respectively), and hence the plutons are weakly peraluminous. Although strongly peraluminous compositions are typical of S-type granitoid rocks (White and Chappell, 1983), many I-type granitoid rocks are weakly peraluminous and several mechanisms, other than sedimentary sources, have been suggested for their origin (e.g., Clarke, 1981).

The Marble Mountain and Big Brook plutons display petrographic features characteristically associated with I-type granitoid suites (White and Chappell, 1983; Whalen and Chappell,
1988), including a mafic mineral assemblage of biotite + hornblende or biotite alone, the accessory minerals magnetite, titanite and allanite, and the presence of hornblende-rich inclusions. They show major-and trace-element similarities to Cordilleran I-type suites, as exemplified by the Peninsular Ranges Batholith, rather than to Caledonian I-type suites such as those of the Caledonian and Lachlan fold belts; for example, low $\mathrm{K}_{2} \mathrm{O}$ (Fig. 8 ) and low incompatible element $(\mathrm{Pb}, \mathrm{Rb}, \mathrm{Th}, \mathrm{U}, \mathrm{K}, \mathrm{La}, \mathrm{Ce})$ contents (Fig. 9).

Classification of the West Bay Pluton is more difficult. Because mineralogical and chemical compositions of felsic granites of various types (I, S, and A) converge, they are difficult to separate or classify (e.g., Whalen et al., 1987). On a $\mathrm{Na}_{2} \mathrm{O}$ versus $\mathrm{K}_{2} \mathrm{O}$ diagram (Fig. 8), the West Bay samples plot closest to the average felsic S-type granite. However, the West Bay Pluton differs from S-type granitoid rocks in its mineralogical features, and also in its lower $\mathrm{CaO}, \mathrm{MgO}$, and $\mathrm{Sr}$, and higher $\mathrm{Ba}$ and $\mathrm{Ni}$ contents. On diagrams devised by Whalen et al. (1987) to distinguish various felsic granite types (Fig. 10), the West Bay samples show a range of compositions from close to A-type to fractionated felsic granites and unfractionated granites. The West Bay Pluton is distinguished from average A-type granitoid rocks by its much lower $\mathrm{Ga} / \mathrm{Al}$ ratio and $\mathrm{Zr}$ content and higher $\mathrm{MgO}$, $\mathrm{TiO}_{2}$, Ni and $\mathrm{V}$ contents. Overall, on the basis of its I-type mineralogy and felsic composition, the West Bay Pluton is clas- 

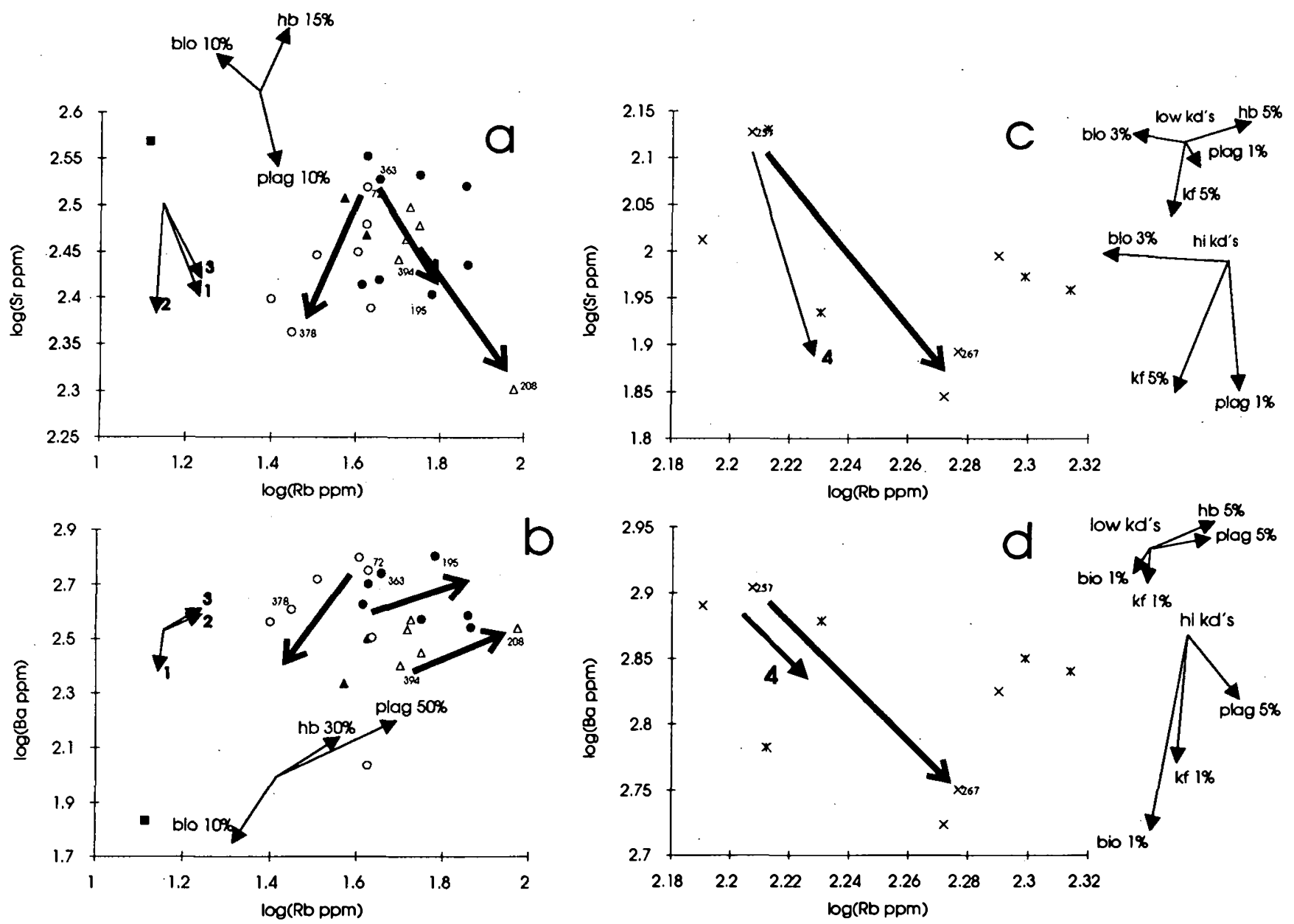

Fig. 6. Plots of $\log \mathrm{Sr}$ versus $\log \mathrm{Rb}$ and $\log \mathrm{Ba}$ versus $\log \mathrm{Rb}$ for the Marble Mountain and Big Brook plutons (a, b) and West Bay monzogranite and porphyry dykes $(c, d)$; symbols as in Figure 2. Bold arrows are visually estimated trends for each unit, which generally follow the sample pairs of Figure 5. Arrows 1 to 4 are trends defined by mass balance mineral ratios from Table 3. Rayleigh mineral fractionation vectors for Marble Mountain and Big Brook plutons were constructed with intermediate partition coefficients from Whalen (1985), and for the West Bay Pluton with both high and low rhyolitic partition coefficients, from Nash and Crecraft (1985).

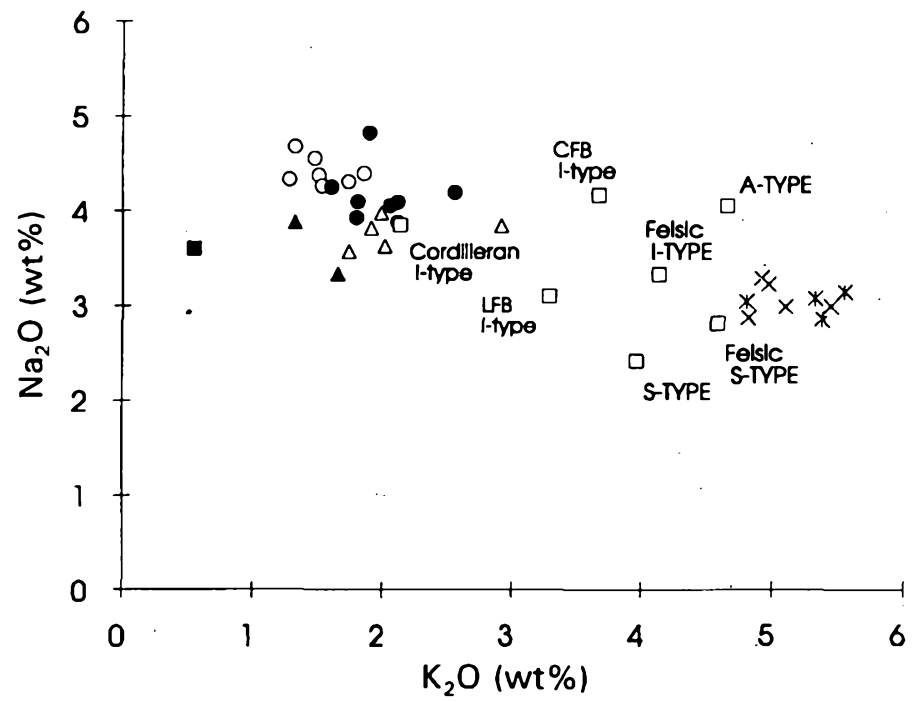

Fig. 7. AFM diagram for samples from the Marble Mountain, Big Brook, and West Bay plutons and associated minor plutons. Tholeiitic/calc-alkaline dividing line after Irvine and Baragar (1971). sified as a "felsic I-type" granite. However, as will be shown, the pluton displays some characteristics which set it apart from typical felsic I-type suites.

Pearce et al. (1984) employed a $\mathrm{Rb}$ versus $\mathrm{Y}+\mathrm{Nb}$ diagram to classify granites (that is, igneous plutonic rocks with greater than 5\% modal quartz) according to tectonic setting (Fig. 11). Samples from the Marble Mountain and Big Brook plutons plot in the volcanic-arc granite field (Fig. 11a), in the same area as rocks from the western Peninsular Ranges Batholith and Jamaica (Fig. 11b). The western Peninsular Ranges Batholith is thought to represent the root zone of a primitive island arc built on oceanic lithosphere at a convergent plate margin (Silver and Chappell, 1988), and Jamaica is a mainly calc-alkalic oceanic arc (Pearce et al., 1984). Samples from the West Bay Pluton straddle the volcanic-arc and within-plate granite fields (Fig. 11a). They plot in the same general area as the average felsic Itype granite, granite from an active continental margin (Chile), and average A-type granite (Fig. 11b).

In order to better interpret the chemical affinity and tectonic setting of the plutons, especially West Bay, an alternative diagram was devised using major element data from known 


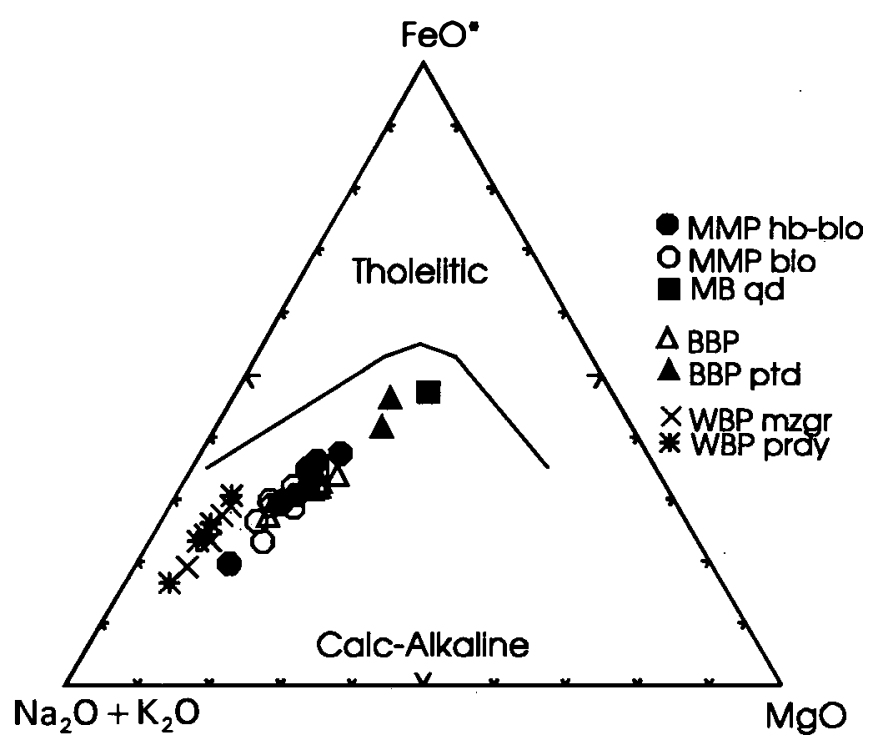

Fig. 8. Plot of $\mathrm{Na}_{2} \mathrm{O}$ against $\mathrm{K}_{2} \mathrm{O}$ for samples from the Marble Mountain, Big Brook, West Bay, and associated minor plutons, with symbols as in Figure 7. Average compositions of various granite types are indicated by open squares; Cordilleran I-type (Peninsular Ranges Batholith), LFB (Lachlan Fold Belt) I-type, and CFB (Caledonian Fold Belt) I-type averages are from Chappell and Stephens (1988); A-type, S-type, felsic I-type, and felsic S-type averages are from Whalen et al. (1987).

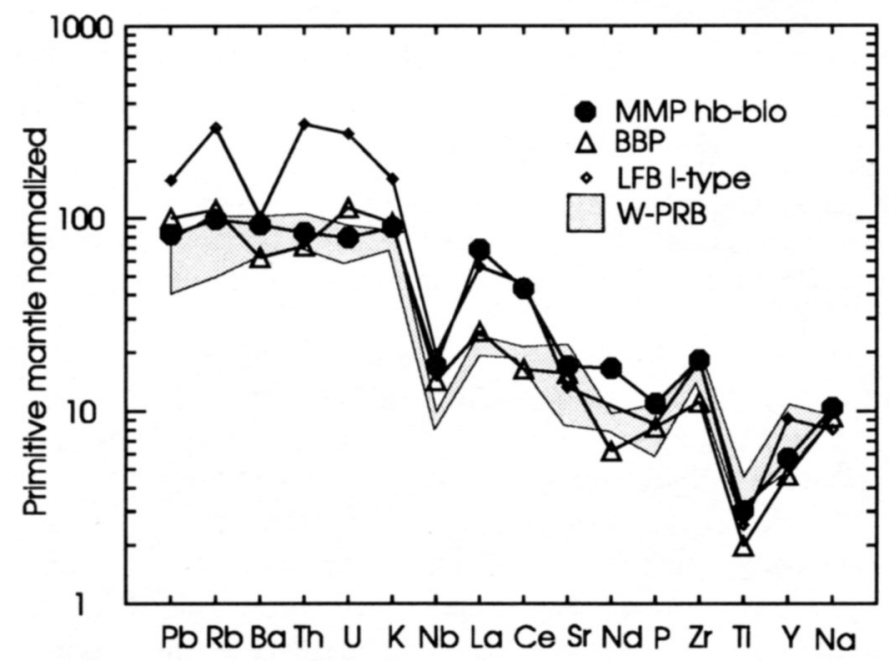

Fig. 9. Primitive mantle-normalized multi-element variation diagram, modified after Wyborn et al. (1992). MMP hb-bio is the average composition of the Marble Mountain hornblende-biotite granodiorite unit, $\mathrm{n}=\mathbf{2}$ for $\mathrm{La}$ and $\mathrm{Ce} ; \mathrm{n}=\mathbf{8}$ for all other elements. BBP is the average composition of the Big Brook Pluton ( $n=2$ for La and Ce; $n=5$ for all other elements). LFB I-type is average Lachlan Fold Belt I-type granitoid after Whalen et al. (1987). W-PRB is the average of domains A, B, and C of Silver and Chappell (1988) in the Western Peninsular Ranges Batholith.

tectonic settings from Pearce et al. (1984). This $\mathrm{K}_{2} \mathrm{O}-\mathrm{FeO}^{* /}$ $\mathrm{MgO}-\mathrm{CaO}$ (KFC) diagram (Fig. 12) appears to be more effective in distinguishing syn- and post-collisional granites from other types than the $\mathrm{Rb}-(\mathrm{Y}+\mathrm{Nb})$ diagram. However, because it involves a highly mobile element $(\mathrm{K})$, the reliability of the diagram for altered rocks, such as those of the West Bay Pluton, is
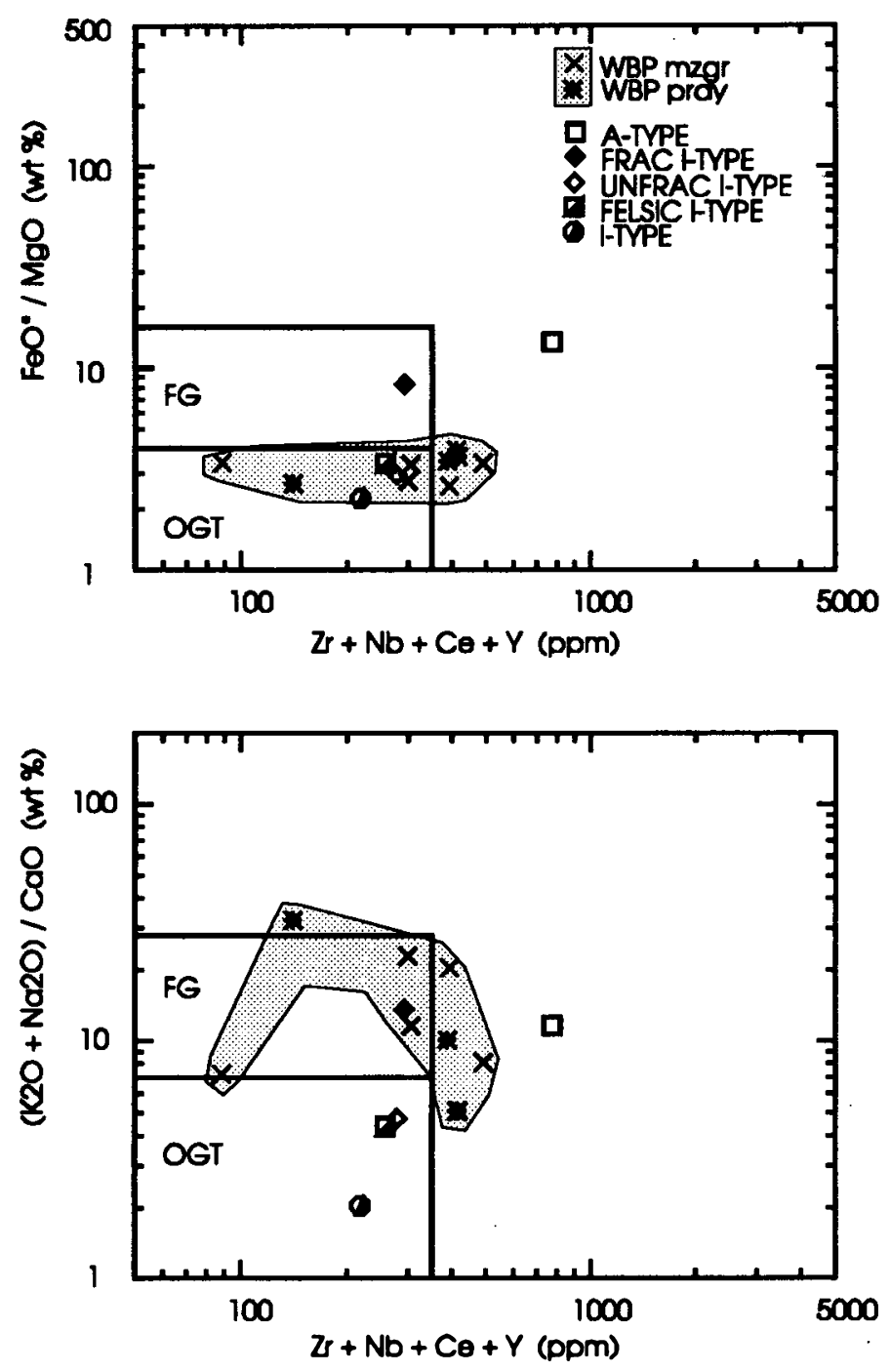

Fig. 10. Plots of $\mathrm{Zr}+\mathrm{Nb}+\mathrm{Ce}+\mathrm{Y}$ versus $\mathrm{FeO} * \mathrm{MgO}$ and $\left(\mathrm{K}_{2} \mathrm{O}+\mathrm{Na}_{2} \mathrm{O}\right) /$ $\mathrm{CaO}$ for West Bay Pluton (WBP mzgr $=$ monzogranite; WBP prdy $=$ porphyry dykes) and average compositions of various granite types: average A-, I-, and felsic I-types from Whalen et al. (1987); unfractionated I-type and fractionated I-type from Chappell and White (1992). FG is field of fractionated felsic granites; OGT is field of unfractionated M-, I-, and S-type granites after Whalen et al. (1987). (Note: J-types are all from the Lachlan Fold Belt.)

uncertain. The West Bay samples plot away from both volcanic arc and within-plate granites, and closest to the field of synand post-collisional granites. They define a trend which is not like those of I-, S-, or A-type granites (Fig. 11c). In contrast, the Marble Mountain and Big Brook samples plot close to the Peninsular Ranges Batholith samples, on a trend toward the average I-type granite.

\section{Petrogenesis}

\section{Marble Mountain and Big Brook plutons}

The Marble Mountain and Big Brook plutons display some chemical similarities to the Western Peninsular Ranges Batholith. In addition, REE patterns of these plutons are also similar (Fig. 4). Gromet and Silver (1987) concluded that the 

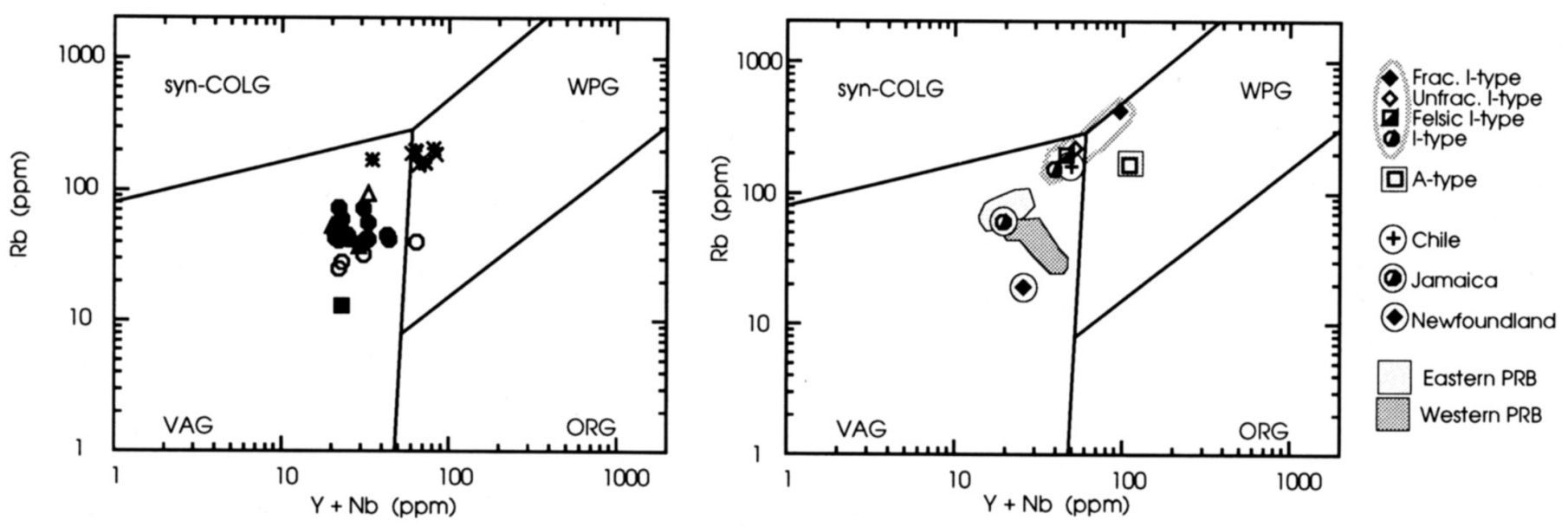

Fig. 11. $\mathrm{Rb}-(\mathrm{Y}+\mathrm{Nb})$ tectonic setting discrimination diagram showing fields for syn-collisional (syn-COLG), volcanic arc (VAG), within plate (WPG), and ocean ridge (ORG) granites after Pearce et al. (1984). Samples plotted are (a) Marble Mountain, Big Brook, and West Bay plutons, symbols as in Figure 2, and (b) average compositions representing various granitoid types and tectonic settings: I-, felsic I-, and A-type from Whalen et al. (1987); unfractionated and fractionated I-type from Chappell and White (1992); oceanic, mainly tholeiitic arc (Newfoundland: $\mathrm{SiO}_{2}=69.5 \%$ ); oceanic, mainly calc-alkaline arc (Jamaica: $\mathrm{SiO}_{2}=68.4 \%$ ); active continental margin, calc-alkaline, high-K calc-alkaline to shoshonitic (Chile: $\mathrm{SiO}_{2}=74.5 \%$ ) from Pearce et al. (1984); and continental margin, Eastern and Western Peninsular Ranges Batholith (PRB) from Silver and Chappell (1988). (Note: I-type averages are from the Lachlan Fold Belt.)

REE patterns and other geochemical features in the Western Peninsular Ranges Batholith indicate partial melting of a largely basaltic source with a plagioclase-rich (gabbroic) residual assemblage. Justino (1991) showed that partial melting of a mafic source leaving a granulite residue composed of $60 \%$ plagioclase and $40 \%$ clinopyroxene produces REE patterns with LREE enrichment and flat HREE similar to those of the Marble Mountain and Big Brook plutons. Hence, these plutons are interpreted to have been derived by partial melting of a largely basaltic source during subduction. However, it is unlikely that the Marble Mountain and Big Brook plutons were part of an island arc because of their association with paragneissic and platformal metasedimentary rocks. Instead, a primitive continental margin volcanic arc is more likely.

\section{West Bay Pluton}

The West Bay Pluton is unlikely to have been derived from a mafic parent magma because of the lack of chemical evidence for substantial fractionation of feldspars, mafic minerals, or Fe$\mathrm{Ti}$ oxides. The apparently high $\mathrm{Ni}$ content of the pluton (17-40 $\mathrm{ppm}$ ) is not consistent with fractional crystallization involving hornblende or Fe-Ti oxides from a mafic source such as average arc andesite, low- $\mathrm{K}$ andesite or high-K andesite, $(\mathrm{Ni}=15$ $\mathrm{ppm}, 18 \mathrm{ppm}$, and $3 \mathrm{ppm}$ respectively; averages from Condie, 1989).

Major element trends in the West Bay Pluton differ from trends displayed by fractionated I- and S-type granites, which have been attributed to fractionation of feldspars (Chappell and White, 1992). In a KFC plot (Fig. 12c), the evolution of average I- and S-type granites to fractionated I- and S-type granites involves a sharp decrease in $\mathrm{CaO}$ and enrichment in $\mathrm{FeO} * \mathrm{MgO}$ with increasing $\mathrm{SiO}_{2}$ content; in contrast, the West Bay Pluton displays enrichment in $\mathrm{K}_{2} \mathrm{O}$ and decrease in $\mathrm{FeO} * \mathrm{MgO}$ with increasing $\mathrm{SiO}_{2}$.

Justino (1991) speculated that the West Bay magma was derived by a high degree of partial melting of a source with intermediate composition $\left(\mathrm{SiO}_{2}=66\right.$ wt. \%; $\mathrm{MgO}, \mathrm{Na}_{2} \mathrm{O}$, and $\mathrm{K}_{2} \mathrm{O}$ contents similar to that of the West Bay Pluton; high $\mathrm{Ba}$ $(\sim 1000 \mathrm{ppm})$ and $\mathrm{Ni}(\sim 45 \mathrm{ppm})$, and high $\mathrm{Nb}$ and $\mathrm{Y}$ contents. If such a large degree of partial melting could occur, it would produce magma similar in composition to the source. The major element composition of the West Bay Pluton, unlike that of fractionated I-type granites, is similar to crustal compositions (Fig. 12a, d). Hence, the West Bay Pluton may have originated by partial melting of largely crustal rocks, possibly leaving a residue of plagioclase and biotite. Paragneisses with only small amounts of K-feldspar have appreciable plagioclase and biotite as residue even after substantial melting (Winkler, 1979). Formation of the West Bay Pluton was most likely unrelated to subduction but instead may have been produced during adiabatic decompression in a period of rapid uplift and erosion, in a post-tectonic setting.

\section{Conclusions}

The Marble Mountain and Big Brook hornblende-biotite tonalitc to granodiorite plutons display typical I-type petrology and calc-alkaline affinity, and show major and trace element similarities to Cordilleran I-type suites, as exemplified by the Peninsular Ranges Batholith (PRB). Major and trace element variations in these plutons can be modeled by liquid-solid fractionation dominated by plagioclase and hornblende \pm biotite. The plutons are interpreted to have formed at a convergent plate margin, and to represent the root zone of a primitive volcanic arc. This model for petrogenesis and tectonic setting is similar to that interpreted by Farrow and Barr (1992) for dioritic to granodioritic plutons of similar age elsewhere in the Bras d'Or terrane.

In contrast, the West Bay Pluton is a highly altered, megacrystic monzogranite. It displays affinities with felsic Itype granites. However, some major and trace element trends in 


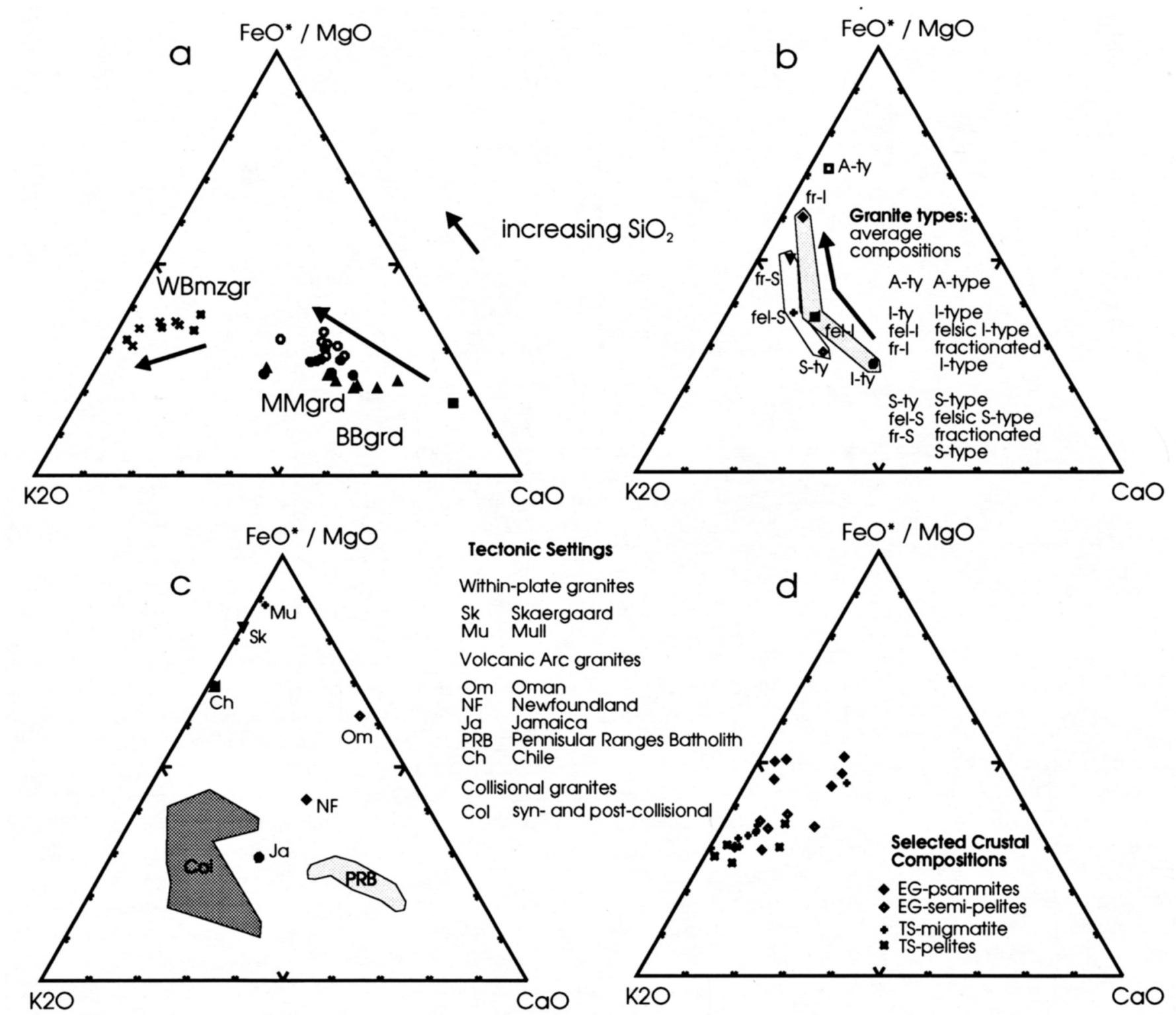

Fig. 12. $\mathrm{K}_{2} \mathrm{O}-\mathrm{FeO} *($ total)/MgO-CaO plots. (a) Marble Mountain (MMgrd) and Big Brook (BBgrd), and West Bay (WBmzgr) plutons, with symbols as in Figure 2. (b) average compositions of I-, felsic I-, S-, felsic S-, and A-type granites from Whalen et al. (1987); fractionated I- and Stype granites from Chappell and White (1992). (c) granitoid rocks from various tectonic settings, from Pearce et al. (1984), except PRB from Silver and Chappell (1988). (d) selected crustal compositions: psammitic and semi-pelitic units of the Proterozoic Erris Group (EG), from Winchester and Max (1989); pelitic and migmatitic compositions of the Trois Seigneurs Massif (TS), from Wickham (1987).

the West Bay Pluton are distinct from those exhibited by felsic I-type granites. They may indicate derivation by a high degree of partial melting of an intermediate crustal composition, leaving a residue consisting of primarily plagioclase and biotite. Tectonic setting of the pluton is unclear but its petrologic characteristics combined with the lack of co-genetic, compositionally expanded granitoid units indicate emplacement in a postorogenic setting. The age of the West Bay Pluton is unknown, but petrological features indicate that it is similar to the ca. 495 granites of the Bras d'Or terrane such as Kellys Mountain Leucogranite (Barr, 1990; Barr et al., 1990; Justino, 1991). If so, then it formed 60 to $70 \mathrm{Ma}$ after the subduction-related ca. 565 to 555 Ma plutons of the Bras. d'Or terrane, and by the definition of Rodgers and Greenberg (1990), could be classified as a post-orogenic granite.

\section{ACKNOWLEDGEMENTS}

This paper is derived mainly from the senior author's M.Sc. thesis project. It was funded by Acadia University graduate fellowships, by research grants to S.M. Barr from the Natural Sciences and Engineering Research Council, and by the Mineral Resources Division of the Geological Survey of Canada through the Canada - Nova Scotia Mineral Development Agreement 1984-89. We thank A.L. Sangster for his support and continuing interest in the North Mountain area. We thank journal reviewers A. Kerr and J. Whalen for their helpful comments which led to significant improvements in the manuscript. 
BARR, S.M. 1990. Granitoid rocks and terrane characterization: an example from the Northern Appalachian Orogen. Geological Journal, 25, pp. 295-304.

BARR, S.M. and RAEside, R.P. 1989. Tectono-stratigraphic terranes in Cape Breton Island, Nova Scotia: Implications for the configuration of the northern Appalachian orogen. Geology, 17, pp. 822 . 825.

BarR, S.M., Dunning, G.R., Raeside, R.P., and Jamieson, R.A. 1990. Contrasting U-Pb ages from plutons in the Bras d'Or and Mira terranes of Cape Breton Island, Nova Scotia. Canadian Journal of Earth Sciences, 27, pp. 1200-1208.

Carten, R.B. 1986. Sodium-calcium metasomatism: chemical, temporal, and spatial relationships at the Yerington, Nevada, porphyry copper deposit. Economic Geology, 81, pp. 1495-1519.

Chappell, B.W. and Stephens, W.E. 1988. Origin of infracrustal (Itype) granite magmas. Transactions of the Royal Society of Edinburgh, Earth Sciences, 79, pp. 71-86.

Chappell, B.W. and White, A.J.R. 1992. I- and S-type granites in the Lachlan Fold Belt. In The Second Hutton Symposium on the Origin of Granites and Related Rocks. Ediled by P.E. Brown and B.W. Chappell. The Geological Socicty of America, Special Paper 272, pp. 1-26.

Chatterjee, A.K. 1980. Mineralization and associated wall rock alteration in the George River Group, Cape Breton Island, Nova Scotia. Unpublished Ph.D. thesis, Dalhousie University, Halifax, Canada, $197 \mathrm{p}$.

Clarke, D.B. 1981. The mineralogy of peraluminous granites: a review. Canadian Mineralogist, 19, pp. 3-17.

Condie, K.C. 1989. Plate Tectonics and Crustal Evolution. Pergamon Press, Oxford, $476 \mathrm{p}$.

DunNing, G.R., BarR, S.M., RAeside, R.P., and JAMIESON, R.A. 1990. U.Pb zircon, titanite, and monazite ages in the Bras d'Or and Aspy terranes of Cape Breton Island, Nova Scotia: implications for magmatic and metamorphic history. Geological Society of America Bulletin, 101, pp. 322-330.

FARROW, C.E.G. and BARR, S.M. 1992. Petrology of high-Al-hornblendeand magmatic-epidote-bearing plutons in the southeastern Cape Breton Highlands, Nova Scotia. Canadian Mineralogist, 30, pp. 377-393.

Fletcher, H. 1881. Report on Surveys in Richmond, Inverness, Guysborough and Antigonish Counties, Nova Scotia. Geological Survey of Canada, Report of Progress 1879-80, Part F, 125 p.

Gromet, L.P. and Silver, L.T. 1987. REE variations across the Peninsular Ranges batholith: implications for batholithic petrogenesis and crustal growth in magmatic arcs. Journal of Petrology, 28, pp. 75-125.

GUERnSEY, T.D. 1928. The geology of North Mountain, Cape Breton. Geological Survey of Canada, Summary Report 1927, Part C, pp. 47-82.

IRVINE, T.N. and BARAGAR, W.R.A. 1971. A guide to the chemical classification of the common volcanic rocks. Canadian Journal of Earth Sciences, 8, pp. 523-548.

Justino, M.F. 1991. Geology and petrogenesis of granitoid rocks in the North Mountain area, southwestern Cape Breton Island, Nova Scotia. Unpublished M.Sc. thesis, Acadia University, Wolfville, Nova Scotia, 336 p.

KeLLEY, D.G. 1967. Baddeck and Whycocomagh Map-Areas. Geological Survey of Canada, Memoir 351, $65 \mathrm{p}$.

KePpie, J.D., Dallmeyer, R.D., and MURPhy, J.B. 1990. Tectonic implications of ${ }^{40} \mathrm{Ar} /{ }^{39} \mathrm{Ar}$ hornblende ages from late ProterozoicCambrian plutons in the Avalon Composite Terrane, Nova Scotia, Canada. Geological Society of America Bulletin, 120, pp. 516528.

Keppie, J.D., Nance, R.D., Murphy, J.B., and Dostal, J. 1991. North- ern Appalachians: Avalon and meguma terranes. In The West African Orogens and Circum-Atlantic Correlatives. Edited by R.D. Dallmeyer and J.P. Laroche. Springer-Verlag, Berlin, pp. 315 333.

LE MAITRE, R.W. 1976. The chemical variability of some igneous rocks. Journal of Petrology, 17, Part 4, pp. 589-637.

McCARThY, T.S. and Groves, D.I. 1979. The Blue Tier Batholith, northeastern Tasmania. Contributions to Mineralogy and Petrology, 71, pp. 193-209.

Milligan, G.C. 1970. Geology of the George River Series, Cape Breton. Nova Scotia Department of Mines, Memoir 7, $111 \mathrm{p}$.

NASH, W.P. and CRECRAFT, H.R. 1985. Partition coefficients for trace elements in silicic magmas. Geochimica et Cosmochimica Acta, 49, pp. 2309-2322.

Pearce, J.A., Harris, N.B., and Tindle, A.G. 1984. Trace element discrimination diagrams for the tectonic interpretation of granitic rocks. Journal of Petrology, 25, pp. 956-983.

Pearce, J.A. and Norry, M.J. 1979. Petrogenetic implications of $\mathrm{Ti}$, $\mathrm{Zr}, \mathrm{Y}$, and $\mathrm{Nb}$ variations in volcanic rocks. Contributions to Mineralogy and Petrology, 69, pp. 33-47

RAEside, R.P. and BARR, S.M. 1990. Geology and tectonic development of the Bras d'Or suspect terrane, Cape Breton Island, Nova Scotia. Canadian Journal of Earth Sciences, 27, pp. 1371-1381.

Rodgers, J.J. and GreEnBerG, J.K. 1990. Late-orogenic, post-orogenic, and anorogenic granites: distinction by major-element and traceelement chemistry and possible origins. Journal of Geology, 98, pp. 291-309.

SAnGSTer, A.L., Justino, M.F., and ThORPE, R.I. 1990a. Metallogeny of the Proterozoic marble-hosted zinc occurrences at Lime Hill and Meat Cove, Cape Breton Island, Nova Scotia. In Mineral Deposit Studies in Nova Scotia, Volume 1. Edited by A.L. Sangster. Geological Survey of Canada, Paper 90-8, pp. 31-66.

Sangster, A.L., Hunt, P.A., and Mortensen, J.K. 1990. U-Pb geochronology of the Lime Hill gneissic complex, Cape Breton Island, Nova Scotia. Atlantic Geology, 26, pp. 229-236.

SILVER, L.T. and CHAPPELL, B.W. 1988. The Peninsular Ranges Batholith: an insight into the evolution of the Cordilleran batholiths of southwestern North America. In The Origin of Granites; A Symposium. Transactions of the Royal Society of Edinburgh, Earth Sciences, 79, pp. 105-121.

Streckeisen, A. 1976. To each plutonic rock its proper name. EarthScience Reviews, 12, pp. 1-33.

Tindle, A.G. and Pearce, J.A. 1981. Petrogenetic modelling of in situ fractional crystallization in zoned Loch Doon pluton, Scotland. Contributions to Mineralogy and Petrology, 78, pp. 196-207.

Whalen, J.B. 1985. Geochemistry of an Island-Arc Plutonic Suite: the Uasilau-Yau Yau Intrusive Complex, New Britain. P.N.G. Journal of Petrology, 26, pp. 603-632.

Whalen, J.B. and Chappell, B.W. 1988. Opaque mineralogy and mafic mineral chemistry of I-type and S-type granites of the Lachlan fold belt, southeast Australia. American Mineralogist, 73, pp. 281296.

Whalen, J.B., Currie, K.L., and Chappell, B.W. 1987. A- type granites: geochemical characteristics, discrimination and petrogenesis. Contributions to Mineralogy and Petrology, 95, pp. 407-419.

Wheatley, M. and Rock, N.M.S. 1988. A Macintosh program to generate normalized multi-element "spidergrams". American Mineralogist, 73, pp. 919-921.

White, A.J.R. and Chappell, B.W. 1983. Granitoid types and their distribution in the Lachlan Fold Belt, southeastern Australia. Geological Society of America, Memoir 159, pp. 21-34.

Wickнам, S. 1987. Crustal anatexis and granite petrogenesis during low-pressure regional metamorphism: the Trois Seigneurs Massif, Pyrenees, France. Journal of Petrology, 28, pp. 127-169. 
WinCHESTER, J.A. and MAX, M. 1989. Tectonic setting discrimination in clastic sequences: an example from the late Proterozoic Erris group. Precambrian Research, 45, pp. 191-201.

WINKLER, H.G.F. 1979. Petrogenesis of Metamorphic Rocks. SpringerVerlag, New York, 348 p.

Wyborn, L.A.I., Wyborn, D., WARren, R.G., and Drummond, B.J. 1992. Proterozoic granite types in Australia: implications for lower crust composition, structure, and evolution. In The Second Hutton Symposium on the Origin of Granites and Related Rocks. Edited by P.E. Brown and B.W. Chappell. The Geological Society of America, Special Paper 272, pp. 201-209. 